\title{
Seven years of IASI ozone retrievals from FORLI: validation with independent total column and vertical profile measurements
}

\author{
Anne Boynard $^{1}$, Daniel Hurtmans ${ }^{2}$, Mariliza E. Koukouli ${ }^{3}$, Florence Goutail ${ }^{1}$, Jérôme Bureau ${ }^{1}$, Sarah Safieddine ${ }^{4}$, \\ Christophe Lerot $^{5}$, Juliette Hadji-Lazaro ${ }^{1}$, Catherine Wespes ${ }^{2}$, Jean-Pierre Pommereau ${ }^{1}$, Andrea Pazmino ${ }^{1}$, \\ Irene Zyrichidou $^{3}$, Dimitris Balis ${ }^{3}$, Alain Barbe ${ }^{6}$, Semen N. Mikhailenko ${ }^{7,8}$, Diego Loyola ${ }^{9}$, Pieter Valks $^{9}$, \\ Michel Van Roozendael $^{5}$, Pierre-François Coheur ${ }^{2}$, and Cathy Clerbaux ${ }^{1,2}$ \\ ${ }^{1}$ LATMOS/IPSL, UPMC Sorbonne Universités, UVSQ, CNRS, Paris, France \\ ${ }^{2}$ Spectroscopie de l'Atmosphère, Chimie Quantique et Photophysique, \\ Université libre de Bruxelles, Brussels, Belgium \\ ${ }^{3}$ Laboratory of Atmospheric Physics, Aristotle University of Thessaloniki, Thessaloniki, Greece \\ ${ }^{4}$ Department of Civil and Environmental Engineering, Massachusetts Institute of Technology, \\ Cambridge, MA, USA \\ ${ }^{5}$ Belgian Institute for Space Aeronomy, Brussels, Belgium \\ ${ }^{6}$ Université de Reims-Champagne-Ardenne, Groupe de Spectrométrie Moléculaire et Atmosphérique, \\ 51062 Reims, France \\ ${ }^{7}$ V.E. Zuev Institute of Atmospheric Optics, Siberian Branch, Russian Academy of Sciences, \\ Academician Zuev Square 1, 634021 Tomsk, Russia \\ ${ }^{8}$ Climate and Environmental Physics Laboratory, Ural Federal University, 19, \\ Mira Avenue, 620002 Yekaterinburg, Russia \\ ${ }^{9}$ Institut für Methodik der Fernerkundung (IMF), Deutsches Zentrum für Luft- und Raumfahrt (DLR), \\ Oberpfaffenhofen, Germany
}

Correspondence to: Anne Boynard (anne.boynard@latmos.ipsl.fr)

Received: 13 January 2016 - Published in Atmos. Meas. Tech. Discuss.: 10 February 2016

Revised: 1 July 2016 - Accepted: 19 July 2016 - Published: 6 September 2016

\begin{abstract}
This paper presents an extensive intercomparison and validation for the ozone $\left(\mathrm{O}_{3}\right)$ product measured by the two Infrared Atmospheric Sounding Interferometers (IASIs) launched on board the MetOp-A and MetOp-B satellites in 2006 and in 2012 respectively. IASI $\mathrm{O}_{3}$ total columns and vertical profiles obtained from Fast Optimal Retrievals on Layers for IASI (FORLI) v20140922 software (running up until recently) are validated against independent observations during the period 2008-2014 on a global scale. On average for the period 2013-2014, IASI-A and IASI-B total ozone columns (TOCs) retrieved using FORLI are consistent, with IASI-B providing slightly lower values with a global difference of only $0.2 \pm 0.8 \%$. The comparison between IASI$\mathrm{A}$ and IASI-B $\mathrm{O}_{3}$ vertical profiles shows differences within $\pm 2 \%$ over the entire altitude range. Global validation results for 7 years of IASI TOCs from FORLI against the Global
\end{abstract}

Ozone Monitoring Experiment-2 (GOME-2) launched on board MetOp-A and Brewer-Dobson data show that, on average, IASI overestimates the ultraviolet (UV) data by 5 $6 \%$ with the largest differences found in the southern high latitudes. The comparison with UV-visible SAOZ (Système d'Analyse par Observation Zénithale) measurements shows a mean bias between IASI and SAOZ TOCs of $2-4 \%$ in the midlatitudes and tropics and $7 \%$ at the polar circle. Part of the discrepancies found at high latitudes can be attributed to the limited information content in the observations due to low brightness temperatures. The comparison with ozonesonde vertical profiles (limited to $30 \mathrm{~km}$ ) shows that on average IASI with FORLI processing underestimates $\mathrm{O}_{3}$ by $\sim 5-15 \%$ in the troposphere while it overestimates $\mathrm{O}_{3}$ by $\sim 10-40 \%$ in the stratosphere, depending on the latitude. The largest relative differences are found in the trop- 
ical tropopause region; this can be explained by the low $\mathrm{O}_{3}$ amounts leading to large relative errors. In this study, we also evaluate an updated version of FORLI-O3 retrieval software (v20151001), using look-up tables recalculated to cover a larger spectral range using the latest HITRAN spectroscopic database (HITRAN 2012) and implementing numerical corrections. The assessment of the new $\mathrm{O}_{3}$ product with the same set of observations as that used for the validation exercise shows a correction of $\sim 4 \%$ for the TOC positive bias when compared to the UV ground-based and satellite observations, bringing the overall global comparison to $\sim 1-$ $2 \%$ on average. This improvement is mainly associated with a decrease in the retrieved $\mathrm{O}_{3}$ concentration in the middle stratosphere (above $30 \mathrm{hPa} / 25 \mathrm{~km}$ ) as shown by the comparison with ozonesonde data.

\section{Introduction}

Despite its small amount, ozone $\left(\mathrm{O}_{3}\right)$ plays very significant roles in the atmosphere. In the stratosphere, $\mathrm{O}_{3}$ protects the biosphere and humans from harmful ultraviolet (UV) radiation. In contrast, $\mathrm{O}_{3}$ in the troposphere is considered as one of the main air pollutants impacting both human health (Brunekreef and Holgate, 2002; Lim et al., 2012) and ecosystems (Fowler et al., 2009). Tropospheric $\mathrm{O}_{3}$ originates either from complex photochemical reactions involving nitrogen oxides $\left(\mathrm{NO}_{x}\right)$, carbon monoxide $(\mathrm{CO})$, and hydrocarbons (e.g., Chameides and Walker, 1973; Crutzen, 1973) or from the stratosphere by downward transport to the troposphere especially at middle and high latitudes (e.g., Holton et al., 1995). Tropospheric $\mathrm{O}_{3}$ is the third most important anthropogenic greenhouse gas after carbon dioxide and methane (IPCC, 2013) and is referred to as a short-lived climate forcing constituent (Shindell et al., 2012). In particular, upper tropospheric $\mathrm{O}_{3}$ affects global outgoing long-wave radiation (Worden et al., 2008) and its changes have a significant impact on the surface temperature (IPCC, 2013). Enhanced upper tropospheric $\mathrm{O}_{3}$ can impact air quality when transported to the boundary layer (Fiore et al., 2002). The lifetime of tropospheric $\mathrm{O}_{3}$ varies with altitude and ranges from 1-2 days in the boundary layer where dry deposition is the major sink to several weeks in the free troposphere (e.g., Stevenson et al., 2006), which is sufficiently long for $\mathrm{O}_{3}$ to be transported intercontinentally (Monks et al., 2015). Thus $\mathrm{O}_{3}$ can influence air quality from urban scale to hemispheric scale (e.g., HTAP, 2010) and there is an obvious need to treat $\mathrm{O}_{3}$ across this range of scales. To this end, new observational opportunities are offered by both satellites and small sensors that bridge the scales (Monks et al., 2015).

Space observation in the nadir geometry is the most efficient way to obtain global information on horizontal distribution of $\mathrm{O}_{3}$, along with coarse information on the vertical. However, retrievals of tropospheric $\mathrm{O}_{3}$ remain challeng- ing since most of the $\mathrm{O}_{3}$ is contained in the stratospheric $\mathrm{O}_{3}$ layer, and the satellite signal integrates both contributions. The first distributions of tropospheric $\mathrm{O}_{3}$ were derived from UV-visible (vis) measurements by subtracting an estimate of the stratospheric component from the measured total column (e.g., Fishman and Larsen, 1987; Fishman et al., 1990). More recently, several studies have developed alternative approaches to tropospheric $\mathrm{O}_{3}$ retrieval from nadirviewing satellite UV spectrometers to have sensitivity to tropospheric $\mathrm{O}_{3}$ (e.g., Miles et al., 2015; Valks et al., 2014).

However, the recently developed thermal infrared (TIR) nadir-viewing spectrometers offer more sensitivity in the troposphere, as demonstrated by the Tropospheric Emission Spectrometer (TES) on board EOS-AURA (e.g., Nassar et al., 2008; Worden et al., 2007) and the Infrared Atmospheric Sounding Interferometer (IASI) on board MetOp-A and B (e.g., Boynard et al., 2009; Dufour et al., 2012). TES and IASI have provided measurements of tropospheric $\mathrm{O}_{3}$ for a large range of applications: atmospheric composition (Boynard et al., 2009; Wespes et al., 2012, 2016), transport (Jones et al., 2008), climate (Doniki et al., 2015; Worden et al., 2008), and air quality (Dufour et al., 2010, 2015; Eremenko et al., 2008; Safieddine et al., 2013, 2014; Verstraeten et al., 2015). Recently, the ability of IASI to detect boundary layer pollution in case of large negative thermal contrast combined with high levels of pollution provided a first step towards the use of TIR sounders to contribute to air quality monitoring, evaluation, and management (Boynard et al., 2014).

Initial validation of IASI total and tropospheric $\mathrm{O}_{3}$ was carried out by Boynard et al. (2009). The paper compares a year of IASI-A measurements to both UV satellite and ground-based observations along with ozonesonde data. More recently, IASI $\mathrm{O}_{3}$ has been validated against independent observations in a series of papers (Antón et al., 2011; Dufour et al., 2012; Gazeaux et al., 2013; Pommier et al., 2012; Oetjen et al., 2014; Safieddine et al., 2015; Scannell et al., 2012; Toihir et al., 2015). These papers report that the comparisons between IASI and UV instruments show a positive bias from IASI for the total column ranging from $\sim 3 \%$ (Brewer-Dobson) to $\sim 6 \%$ (Global Ozone Monitoring Experiment-2A - GOME-2A) on the global scale. For the vertical profile, the bias is generally lower than $10 \%$, except in the $10-25 \mathrm{~km}$ altitude range where a positive bias of 10 $15 \%$ is reported (Dufour et al., 2012; Gazeaux et al., 2013). However, these different studies focused on a particular region and/or a relatively short period of time.

The purpose of the present paper is to provide an update on the $\mathrm{O}_{3}$ retrievals using the Fast Optimal Retrievals on Layers for IASI (FORLI) software (Hurtmans et al., 2012) that allows one to systematically retrieve global distributions of $\mathrm{O}_{3}$ vertical profiles in a near-real-time mode. The main aim of this work is (1) to extend the IASI-A $\mathrm{O}_{3}$ validation to the 2008-2014 period and with a range of different instruments such as satellite sensors, Brewer-Dobson spectrophotometers, SAOZ (Système d'Analyse par Observation Zénithale) 
instruments, and ozonesondes and (2) to quantify the consistency between the $\mathrm{O}_{3}$ retrieved by the second IASI instrument (IASI-B) with that of IASI-A. The next section provides a description of the IASI $\mathrm{O}_{3}$ measurements including the IASI instrument and the $\mathrm{O}_{3}$ profile retrieval processing. Section 3 presents an intercomparison between $\mathrm{O}_{3}$ derived from IASI-A and IASI-B. In Sects. 4 and 5 the results of the validation of total $\mathrm{O}_{3}$ columns (TOCs) and vertical profiles are presented respectively. Section 6 provides preliminary results on an updated version of the retrieval algorithm. Conclusions are given in Sect. 7.

\section{IASI ozone retrievals}

\subsection{The IASI instrument}

IASI was designed for operational meteorology and for monitoring atmospheric chemistry and climate. It is a TIR Fourier transform spectrometer (Clerbaux et al., 2009, 2015) on board the MetOp-A and B satellites, which were launched in October 2006 and September 2012 respectively. The launch of the third and last satellite (MetOp-C) is scheduled for 2018. The role of MetOp-C is to ensure the continuity of observations from a polar orbit started at the beginning of the MetOp mission. The IASI instruments will provide homogeneous long-term data sets of 15 years related to atmospheric composition.

Both IASI-A and B instruments have been operationally sounding the atmosphere since October 2007 and March 2013 respectively. The MetOp-A and B satellites are on a polar, sun-synchronous orbit (about $817 \mathrm{~km}$ altitude) with Equator crossing times of 09:30 (21:30) local mean solar time for the descending (ascending) part of the orbit. IASI is nadir viewing and measures the radiation emitted from the Earth's surface and absorbed and emitted by the atmosphere in the TIR spectral range, between 645 and $2760 \mathrm{~cm}^{-1}$ with an apodized spectral resolution of $0.5 \mathrm{~cm}^{-1}$ and radiometric noise of $0.2 \mathrm{~K}$ (for a reference temperature of $280 \mathrm{~K}$ ) in the $\mathrm{O}_{3}$ spectral absorption region (near $9.6 \mu \mathrm{m}$ ). Because of the nadir geometry complemented by off-nadir measurements up to $48.3^{\circ}$ on both sides of the satellite track (swath of about $2200 \mathrm{~km}$ ), each IASI instrument covers the globe twice a day, providing more than 1.3 million spectra each day. At nadir, each IASI instantaneous field of view is composed of four individual ground pixels of $12 \mathrm{~km}$ diameter each.

\subsection{Ozone retrievals with FORLI}

Retrievals of $\mathrm{O}_{3}$ global distributions have been systematically performed in a near-real-time mode using the FORLIO3 v20140922 software (Hurtmans et al., 2012), which was until a few weeks ago the reference FORLI version. In this study we used the IASI-A and IASI-B $\mathrm{O}_{3}$ data retrieved from January 2008 and from March 2013, respectively, until December 2014. FORLI-O3 is based on the optimal estimation method (OEM) (Rodgers, 2000) and relies on tabulated absorption cross sections at various pressures and temperatures to speed up the radiative transfer calculation. The OEM uses a priori information to constrain ill-posed problems such as $\mathrm{O}_{3}$ concentration retrievals from nadir-viewing spaceborne sounders. The OEM also provides an error budget associated with the retrievals and diagnostic variables allowing accurate comparisons with other data. In particular, the averaging kernel matrix characterizing the sensitivity of the retrieved state to the true state is provided for each retrieval. The position of its peak gives the altitude of maximum sensitivity, while its full width at half maximum is an estimation of the vertical resolution of the retrieved state (Rodgers, 2000). The trace of this matrix, called degrees of freedom for signal (DOFS), represents the number of independent pieces of information contained in the measurements, which gives an estimation of the vertical sensitivity of the retrievals.

The $\mathrm{O}_{3}$ retrieval spectral range is $1025-1075 \mathrm{~cm}^{-1}$, which is dominated by $\mathrm{O}_{3}$ lines with only few water vapor lines and a weak absorption contribution of methanol (Hurtmans et al., 2012). The a priori information consists of a covariance matrix $\mathbf{S}_{\mathrm{a}}$ constructed from the McPeters/Labow/Logan climatology of $\mathrm{O}_{3}$ profiles, which combines long-term satellite limb observations and measurements from $\mathrm{O}_{3}$ sondes (McPeters et al., 2007) and a global a priori profile $\boldsymbol{x}_{\mathrm{a}}$ that is the mean of the ensemble. Therefore only one single $\mathrm{O}_{3}$ a priori profile and variance-covariance matrix are used in FORLI. The $\mathrm{O}_{3}$ product from FORLI is a vertical profile retrieved on 40 layers between surface and $40 \mathrm{~km}$, with an extra layer from $40 \mathrm{~km}$ to the top of the atmosphere. It is provided along with averaging kernels and relative total error profile, on the same vertical grid. In order to avoid cloud contaminated scenes, retrievals are only performed for clear or almost-clear scenes with a fractional cloud cover below $13 \%$, identified using the cloud information from the EUMETSAT operational processing (August et al., 2012). A second filter is applied to keep only the more reliable data by removing those corresponding to poor spectral fits (root mean square of the spectral fit residual higher than $3.5 \times 10^{-8} \mathrm{~W} \mathrm{~cm}^{-2} \mathrm{srcm}^{-1}$ ). For a full description of the FORLI-O3 software and the OEM algorithm the reader is referred to Hurtmans et al. (2012).

Figure 1 illustrates an example of averaging kernels for one midlatitude IASI observation on 15 July 2014. The averaging kernels present four maxima located around 2, 8, 15, and $22 \mathrm{~km}$, and the total DOFS is 4.2 . As shown in previous studies, the IASI sensitivity to tropospheric $\mathrm{O}_{3}$ peaks between 6 and $8 \mathrm{~km}$, with some seasonal variability (e.g., Clerbaux et al., 2015). However, in case of significant thermal contrast (i.e., the difference of temperature between the ground and the atmospheric layer just above it), the sensitivity of IASI increases near the surface (Boynard et al., 2014). For the example illustrated in Fig. 1, the measurement is performed at a location associated with a large thermal contrast $(18 \mathrm{~K})$ and hence the averaging kernels corresponding to the 


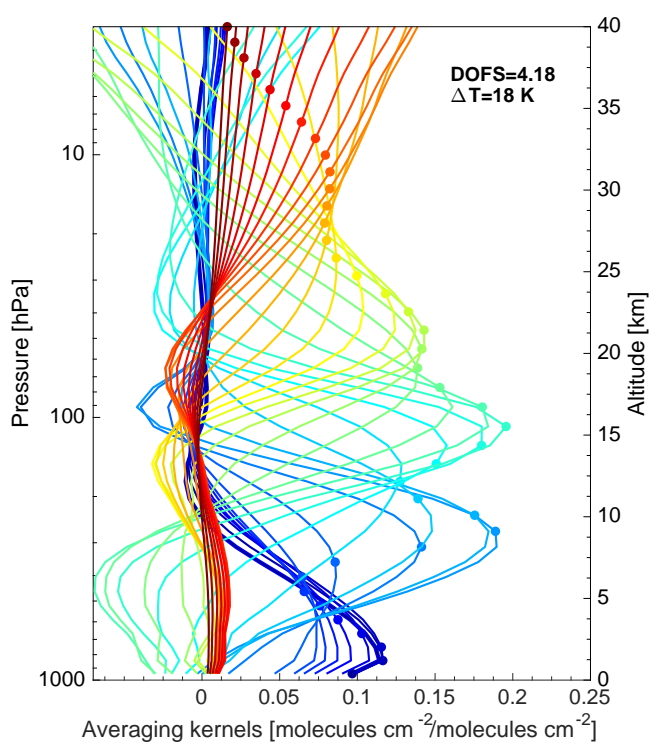

Figure 1. Example of IASI-A averaging kernel functions corresponding to one daytime midlatitude measurement $\left(31.3^{\circ} \mathrm{N}\right.$, $46.7^{\circ} \mathrm{E}$ ) obtained on 15 July 2014 for each $1 \mathrm{~km}$ retrieved layer from the surface to $40 \mathrm{~km}$ altitude (color scale). The total DOFS and thermal contrast are also indicated.

troposphere exhibit two maxima, allowing the separation of the boundary layer and the free tropospheric $\mathrm{O}_{3}$ concentrations.

In order to get a global view of IASI vertical sensitivity and its relation with surface temperature, Fig. 2 illustrates the spatial distribution of surface temperature along with total DOFS for the period 2008-2014 for daytime measurements. Data were averaged monthly over a $1^{\circ} \times 1^{\circ}$ grid cell, then the monthly data were averaged over the period 2008-2014. The mean values of surface temperature and DOFS for the $\mathrm{O}_{3}$ profiles for different seasons and latitude bands are given in Table 1. As expected, surface temperature varies with latitude and season, with the highest values found in the tropics during summer $(\sim 300 \mathrm{~K}$ on average) and the lowest values in the high latitudes especially over Antarctica (245-255 K). Same patterns are observed for the DOFS global distribution with the lowest values at high latitude $(\sim 2)$ and the highest values in the tropics $(>4)$, which indicates that IASI is more sensitive in the tropics. There is no significant seasonal change in either surface temperature or DOFS in the tropics and southern midlatitudes. However, at high latitudes and in the northern midlatitudes, surface temperature and DOFS can differ by $10-30 \mathrm{~K}$ and 0.7 , respectively, between winter and summer.

The total error on the $\mathrm{O}_{3}$ profile retrievals is estimated statistically in FORLI, and different contributions to the total error can be isolated: from the limited vertical sensitivity, from the measurement noise, and from uncertainties on fitted (water vapor column) or fixed (e.g., surface emissivity, temperature profile) parameters (Hurtmans et al., 2012). The errors introduced by the uncertainties on the temperature profile can contribute up to $10 \%$ of the total error (Boynard et al., 2009) and, thus, can have an impact on the retrievals. The total error on the vertical $\mathrm{O}_{3}$ profile depends on the latitude and the season, reflecting, amongst other, the influence of signal intensity (Wespes et al., 2016). It generally varies between 10 and $30 \%$ in the troposphere and in the upper troposphere and lower stratosphere (UTLS) and $5 \%$ in the stratosphere. However, larger relative errors are found in the tropics, which are related with the low $\mathrm{O}_{3}$ amounts (Wespes et al., 2016) and in the high latitudes often characterized by low brightness temperatures as shown in Fig. 2.

\section{Intercomparison between IASI-A and IASI-B ozone content}

Several intercomparison exercises between IASI-A and IASI-B radiance spectra have been performed in the framework of the Global Space Based Inter-Calibration System (GSICS; http://gsics.wmo.int/). An excellent consistency between both sensors has been demonstrated, with radiometric biases lower or equal to $0.1 \mathrm{~K}$ and spectral biases lower than $1 \mathrm{ppm}$, which is compliant with the specification of $0.5 \mathrm{~K}$ and 2 ppm, respectively, defined by the Centre National d'Etudes Spatiales (CNES) (see IASI quarterly performance reports at https://iasi.cnes.fr/fr/IASI/Fr/lien1_car_instr.htm).

The comparison between IASI-A and IASI-B $\mathrm{O}_{3}$ products retrieved with FORLI is not straightforward since the pixels are not co-localized in time and space. The two MetOp satellites are on the same orbit with a $180^{\circ}$ shift; therefore there are numerous common observations between two consecutive tracks. However, there is a $\sim 50$ min temporal shift between both instruments (one satellite might be before or after the other); thus the observations are never simultaneous. In addition, the geometry of the observations is different and generally off-nadir with opposite angles, so the location of the observation between the two instruments varies and thus the pixels are not geographically co-localized. Moreover, each IASI $\mathrm{O}_{3}$ measurement is associated with a cloud flag (see Sect. 2), so one observation seen at a certain location with IASI-A might be contaminated by clouds and filtered out in the retrieval processing, while it might not be the case with IASI-B. To overcome these challenges and to be able to compare the measurements over the same basis, the intercomparison of IASI-A and IASI-B TOC retrievals from FORLI is performed on monthly averaged data, over a $1^{\circ} \times 1^{\circ}$ grid.

Figure 3 illustrates the monthly mean relative differences $(100 \times($ IASI-A - IASI-B) / IASI-A) of TOCs for the year 2014 as a function of month and latitude for daytime measurements (left panel) and nighttime measurements (right panel). IASI pixels are considered daytime and nighttime data if the solar zenith angle (SZA) is $<90^{\circ}$ and $>=90^{\circ}$ respectively. An excellent agreement between both IASI-A and 

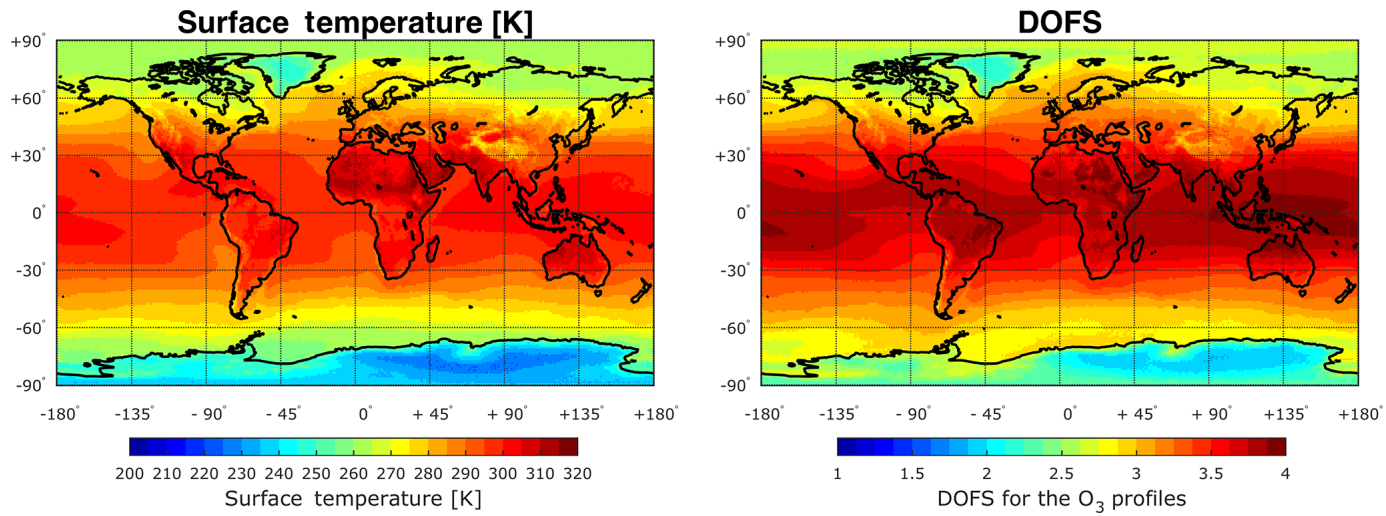

Figure 2. Global distribution averaged over $1^{\circ} \times 1^{\circ}$ for the period 2008-2014 for daytime measurements: (left) IASI surface temperature and (right) DOFS for the $\mathrm{O}_{3}$ profiles.

Table 1. Mean values of surface temperature (K) and DOFS for the $\mathrm{O}_{3}$ profiles for different seasons and latitude bands for the period 2008-2014 for daytime measurements. The standard deviation is also indicated.

\begin{tabular}{|c|c|c|c|c|c|c|c|c|}
\hline \multirow[t]{2}{*}{ Latitude range } & \multicolumn{2}{|c|}{ Dec-Jan-Feb } & \multicolumn{2}{|c|}{ Mar-Apr-May } & \multicolumn{2}{|c|}{ Jun-Jul-Aug } & \multicolumn{2}{|c|}{ Sep-Oct-Nov } \\
\hline & $\begin{array}{r}\text { Surface } \\
\text { temperature }\end{array}$ & DOFS & $\begin{array}{r}\text { Surface } \\
\text { temperature }\end{array}$ & DOFS & $\begin{array}{r}\text { Surface } \\
\text { temperature }\end{array}$ & DOFS & $\begin{array}{r}\text { Surface } \\
\text { temperature }\end{array}$ & DOFS \\
\hline $60-90^{\circ} \mathrm{N}$ & $250 \pm 3$ & $2.31 \pm 0.11$ & $260 \pm 2$ & $2.50 \pm 0.06$ & $277 \pm 2$ & $2.98 \pm 0.05$ & $265 \pm 2$ & $2.72 \pm 0.08$ \\
\hline $30-60^{\circ} \mathrm{N}$ & $273 \pm 4$ & $2.91 \pm 0.09$ & $285 \pm 2$ & $3.14 \pm 0.06$ & $295 \pm 2$ & $3.41 \pm 0.05$ & $287 \pm 2$ & $3.28 \pm 0.05$ \\
\hline $0-30^{\circ} \mathrm{N}$ & $298 \pm 2$ & $3.72 \pm 0.04$ & $301 \pm 2$ & $3.73 \pm 0.03$ & $302 \pm 3$ & $3.74 \pm 0.03$ & $301 \pm 2$ & $3.79 \pm 0.03$ \\
\hline $0-30^{\circ} \mathrm{S}$ & $299 \pm 2$ & $3.76 \pm 0.03$ & $299 \pm 1$ & $3.76 \pm 0.03$ & $296 \pm 1$ & $3.67 \pm 0.04$ & $298 \pm 2$ & $3.69 \pm 0.04$ \\
\hline $30-60^{\circ} \mathrm{S}$ & $284 \pm 2$ & $3.25 \pm 0.04$ & $283 \pm 1$ & $3.22 \pm 0.03$ & $280 \pm 1$ & $3.13 \pm 0.04$ & $280 \pm 2$ & $3.12 \pm 0.04$ \\
\hline $60-90^{\circ} \mathrm{S}$ & $255 \pm 2$ & $2.52 \pm 0.07$ & $247 \pm 2$ & $2.15 \pm 0.06$ & $246 \pm 2$ & $2.65 \pm 0.12$ & $245 \pm 2$ & $2.70 \pm 0.08$ \\
\hline
\end{tabular}

IASI-B TOCs is observed, with differences generally within $1 \%$ for all latitudes, which could be due to both the temporal gap and the different observation geometry leading to different sampling of IASI-A and IASI-B. The larger differences observed in March 2014 around $60^{\circ} \mathrm{N}$ are related to missing IASI-B data during several days due to a temporary problem related to the IASI-B instrument. In polar regions, a possible reason for the larger differences is the combination of the overlap by consecutive orbits with different time and, thus, different meteorological conditions. MetOp, with its polar orbit, makes 14 revolutions per day and will therefore pass by the poles on each revolution. This will lead to a larger number of observations over the poles each day at different times for the same grid cell. The variability in $\mathrm{O}_{3}$ is therefore much larger, leading to both larger differences between the measurements and larger standard deviation (not shown). On average for the period 2013-2014, IASI-A and IASI-B TOCs retrieved using FORLI are consistent, with IASI-B providing slightly lower values with a global difference of only $0.2 \pm 0.8 \%$.

We investigated in more detail the differences between IASI-A and IASI-B $\mathrm{O}_{3}$ by performing a comparison of the FORLI $\mathrm{O}_{3}$ vertical profiles. Figure 4 shows the monthly mean relative differences of $\mathrm{O}_{3}$ vertical profiles for the year
2014 as a function of month and altitude for different latitude bands. Overall the differences between IASI-A and IASI$\mathrm{B} \mathrm{O}_{3}$ concentrations are within $\pm 2 \%$ for the entire altitude range. IASI-A tends to measure less $\mathrm{O}_{3}$ in the troposphere and in the stratosphere above $\sim 25-30 \mathrm{~km}$ and more $\mathrm{O}_{3}$ in the lower/middle stratosphere (LMS) compared to IASIB. Locally, larger differences are also found, especially in the Antarctic region (values $<-10 \%$ in the $10-15 \mathrm{~km}$ altitude range for the January-July period) and in the northern midlatitudes (differences up to $-6 \%$ in the spring season). The lower differences are found above $20 \mathrm{~km}$, where most of $\mathrm{O}_{3}$ is located (differences $<0.5 \%$ ). The main differences are found in the troposphere and near the surface: on average IASI-A measures $2.0 \pm 0.2 \%$ less tropospheric $\mathrm{O}_{3}$ than IASI-B. As shown in Fig. 5, the standard deviation of the relative differences between IASI-A and IASI-B $\mathrm{O}_{3}$ vertical profiles ranges between 5 and $20 \%$ for the entire altitude range and is larger in the tropopause region, characterized by low $\mathrm{O}_{3}$ concentrations, large natural variability, and a strong dependency on the tropopause altitude. It is much larger in the Antarctic region $(>=20 \%)$ for the January-August period, and the causes are not yet fully explained. 

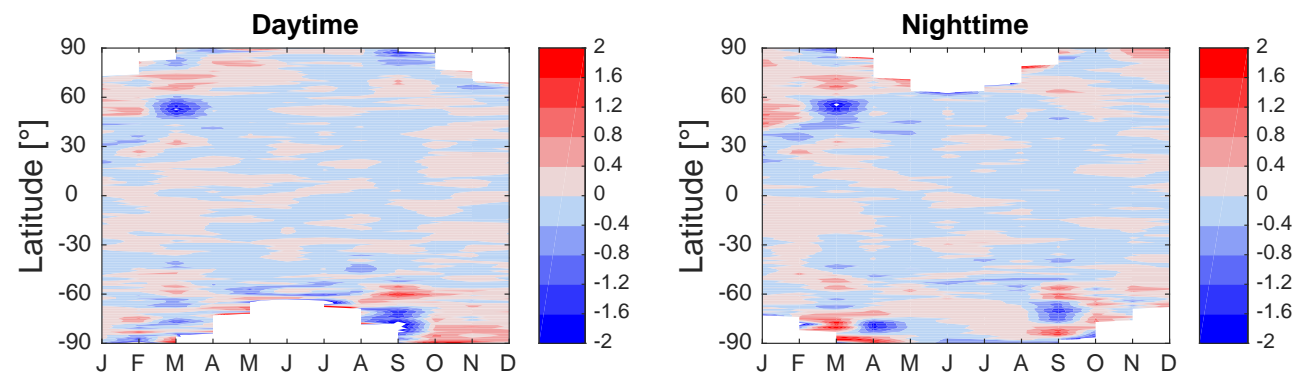

Figure 3. Contour representation of the monthly relative difference (in percent) between IASI-A and IASI-B total ozone column retrieved using FORLI as a function of latitude and time for the year 2014 for daytime data (left) and nighttime data (right). The relative differences are calculated as $100 \times($ IASI-A - IASI-B) $/$ IASI-A.
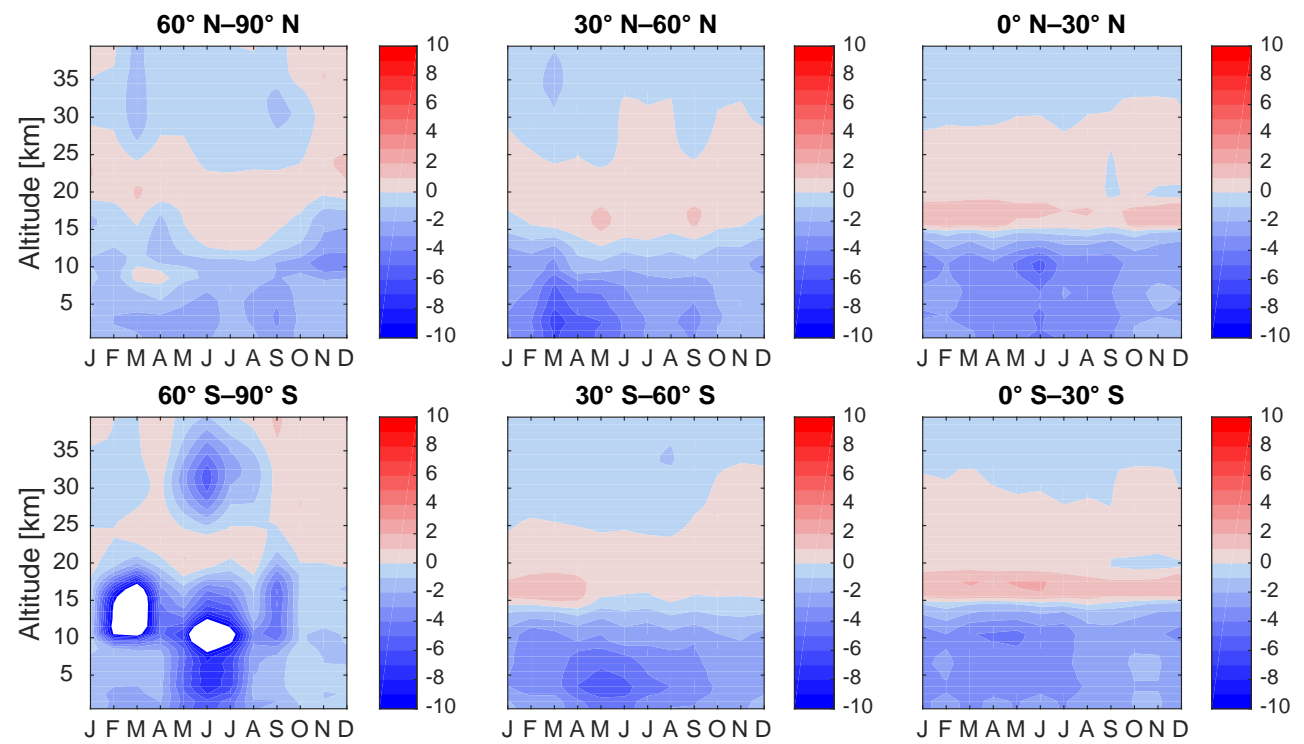

Figure 4. Contour representation of the relative difference (in percent) between IASI-A and IASI-B ozone concentrations as a function of altitude and time for the year 2014 for daytime data. The relative differences are calculated as $100 \times($ IASI-A - IASI-B) / IASI-A. The white area located in the southern high latitudes corresponds to differences ranging between -20 and $-10 \%$.

\section{Validation of total ozone column}

\subsection{Comparison with GOME-2 retrievals}

The GOME-2 instrument, also on board the MetOp-A and B platforms, is a UV-vis-NIR (near IR) nadir-viewing spectrometer covering the spectral range from 240 to $790 \mathrm{~nm}$ with a spectral sampling of $0.11-0.22 \mathrm{~nm}$ and a spectral resolution of $0.24-0.53 \mathrm{~nm}$ (Munro et al., 2016). The maximum swath is about $1920 \mathrm{~km}$, providing almost global coverage of the sunlit part of the atmosphere within 1 day. The reader is kindly referred to Munro et al. (2016) for a full description of the instrument design, calibration, and L1 processing and to Hassinen et al. (2016) for a description of the full suite of GOME2 L2 operational products. In this study, two different TOC products from GOME-2/MetOp-A (GOME-2A) were used for the validation of IASI TOCs from FORLI: (1) GOME2 TOC data that have been generated as part of the EU-
METSAT Ozone Monitoring and Atmospheric Composition Satellite Application Facility (O3M SAF) with the GOME Data Processor (GDP) operational algorithm, which is an iterative differential optical absorption spectroscopy (DOAS) air-mass factor fitting algorithm and uses the ozone absorption features in Huggins band between 325 and $335 \mathrm{~nm}$ (Loyola et al., 2011; Hao et al., 2014); and (2) GOME-2 TOC data generated as part of the ESA Ozone Climate Change Initiative (O3-CCI) with the GOME-type Direct Fitting (GODFIT) algorithm (Van Roozendael et al., 2012; Lerot et al., 2014) and publicly available at http://www.esa-ozone-cci.org. The GOME-2 O3M SAF and CCI TOC products have been validated using ground-based measurements (e.g Hao et al., 2014; Koukouli et al., 2012, 2015; Loyola et al., 2011), which has shown an overall agreement within $1 \%$ in most situations. Note that in this section (and in Sect. 6) only the re- 


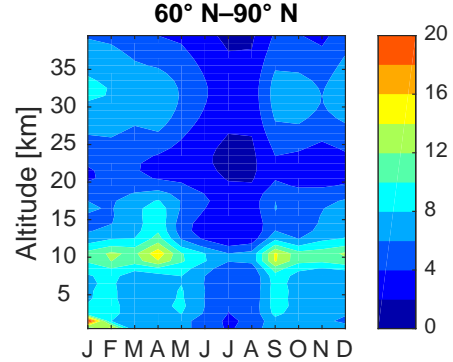

$60^{\circ} \mathrm{S}-90^{\circ} \mathrm{S}$

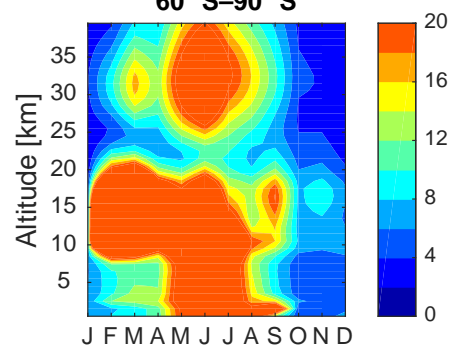

$30^{\circ} \mathrm{N}-60^{\circ} \mathrm{N}$

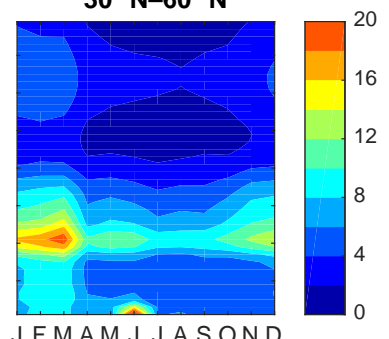

$30^{\circ} \mathrm{S}-60^{\circ} \mathrm{S}$

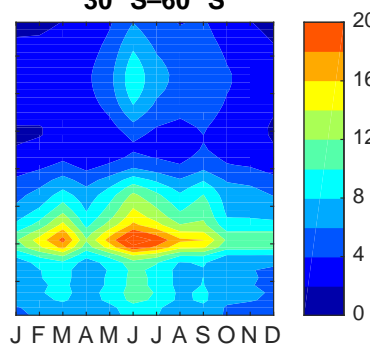

$0^{\circ} \mathrm{N}-30^{\circ} \mathrm{N}$

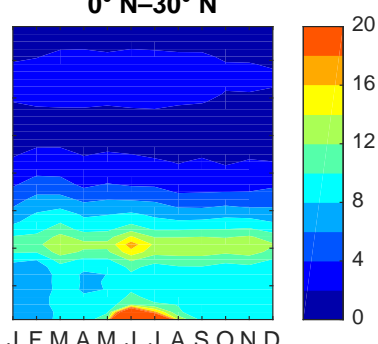

$0^{\circ} \mathrm{S}-30^{\circ} \mathrm{S}$

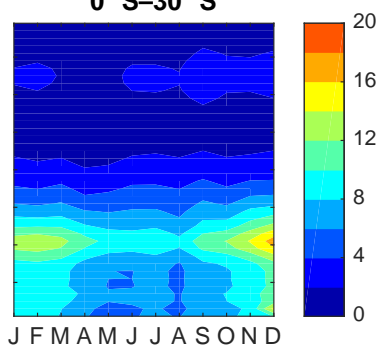

Figure 5. Contour representation of the standard deviation of the differences shown in Fig. 4 (in percent) as a function of altitude and time for the year 2014 for daytime data.

sults related to the IASI and GOME-2A TOC data generated within the EUMETSAT O3M SAF are presented.

The validation of IASI TOC retrievals from FORLI, IASI and GOME-2A pixels is performed with monthly averaged data over the period 2008-2014, over a constant $1^{\circ} \times 1^{\circ}$ grid. As the UV-vis instrument provides daytime observations, only the IASI daytime data $\left(\mathrm{SZA}<90^{\circ}\right)$ are used in this comparison. Figure 6 shows the global distributions of TOCs obtained from the IASI-A and GOME-2A O3M SAF retrievals along with the associated relative differences, calculated as $100 \times($ IASI - GOME-2) / GOME-2, for different seasons of the period 2008-2014. Although, when compared to GOME-2A, IASI-A overestimates $\mathrm{O}_{3}$, similar spatial and seasonal patterns are observed by both instruments. The spatial distribution of total $\mathrm{O}_{3}$ varies strongly with latitude, the largest values occurring at middle and high latitudes during all seasons. This is due to the production rates of $\mathrm{O}_{3}$ from solar UV radiation that are generally highest in the tropics and the large-scale air circulation in the stratosphere that transports $\mathrm{O}_{3}$ from the tropics toward the poles (Dessler, 2000). This results in $\mathrm{O}_{3}$ accumulation at middle and high latitudes, increasing the $\mathrm{O}_{3}$ layer thickness and thus total $\mathrm{O}_{3}$. In contrast, the lowest values of total $\mathrm{O}_{3}$ are located in the tropics for all seasons (except for the Antarctic $\mathrm{O}_{3}$ hole season in September-October-November) because the $\mathrm{O}_{3}$ layer is smaller there (Dessler, 2000). Little seasonal change in total $\mathrm{O}_{3}$ is found in the tropics compared to the polar regions. This is due to the smaller seasonal changes in both sunlight and $\mathrm{O}_{3}$ transport in the tropics than in polar regions. Although the largest differences between the two instruments are observed over Antarctica, the annual Antarctic $\mathrm{O}_{3}$ depletion in the austral spring season (September-October-November) is well observed by both instruments. It is worth mentioning that in contrast to UV-vis instruments (e.g., GOME-2 and OMI), IASI can measure the ozone distribution over the whole South Pole region during the austral winter. Scannell et al. (2012) demonstrated IASI's ability to capture the seasonal characteristics of the ozone hole, in particular during polar winters, despite the low surface temperature and therefore the lower IASI sensitivity.

Figure 7 shows the time series of the monthly mean relative difference between IASI-A in blue and IASI-B in red against GOME-2A O3M SAF gridded TOCs along with the standard deviation for different latitudinal bands. The three main features that arise from this figure are (i) the excellent agreement between the IASI-A and the IASI-B comparisons, (ii) the systematic overestimation of IASI with FORLI processing, and (iii) the pronounced seasonality in the difference between IASI and GOME-2A TOCs, the lowest differences being found in summer and the largest differences in winter. The lowest differences are found in the middle latitudes $(2-4 \%)$ and the tropics $(\sim 4-6 \%)$ while the highest differences are found at high latitudes, especially over Antarctica (up to $30 \%$ during the austral summer season). It is worth noting that in the tropics there is a small drift visible in the last 2 years (2013-2014), which is not apparent in the comparisons between IASI and ground-based TOCs (see Figs. 11 and 12). This may be related to the instrumental degradation of GOME-2A in recent years (Munro et al., 2016).

Table 2 gives some statistics related to the differences between IASI-A with FORLI processing and GOME-2A O3M SAF TOCs separately for each season, at global scale and for six different latitude zones. The monthly data were averaged seasonally as performed in Fig. 6 and then correlations were 
IASI
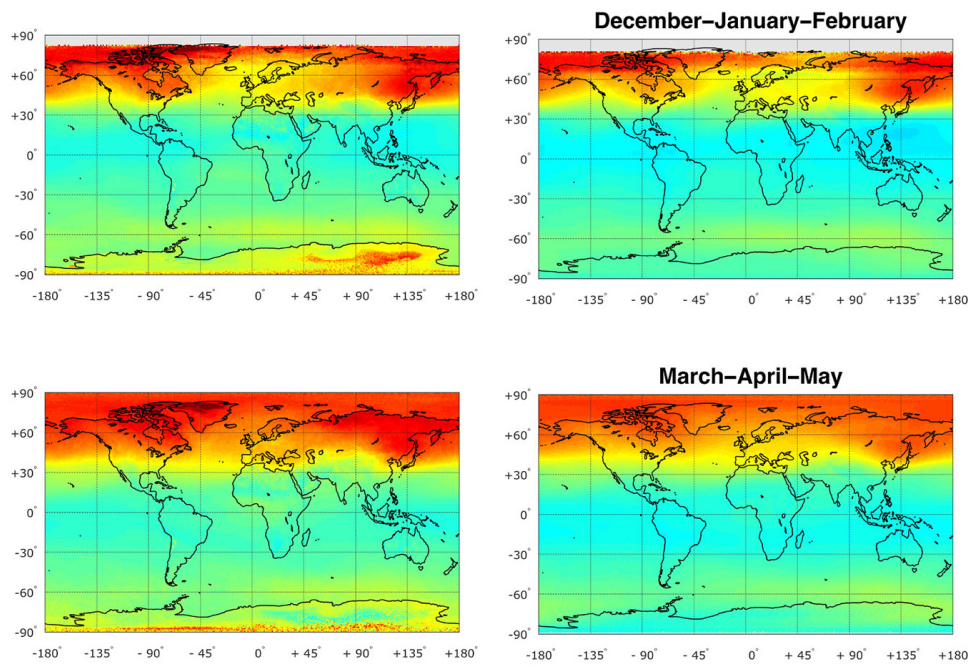

GOME-2
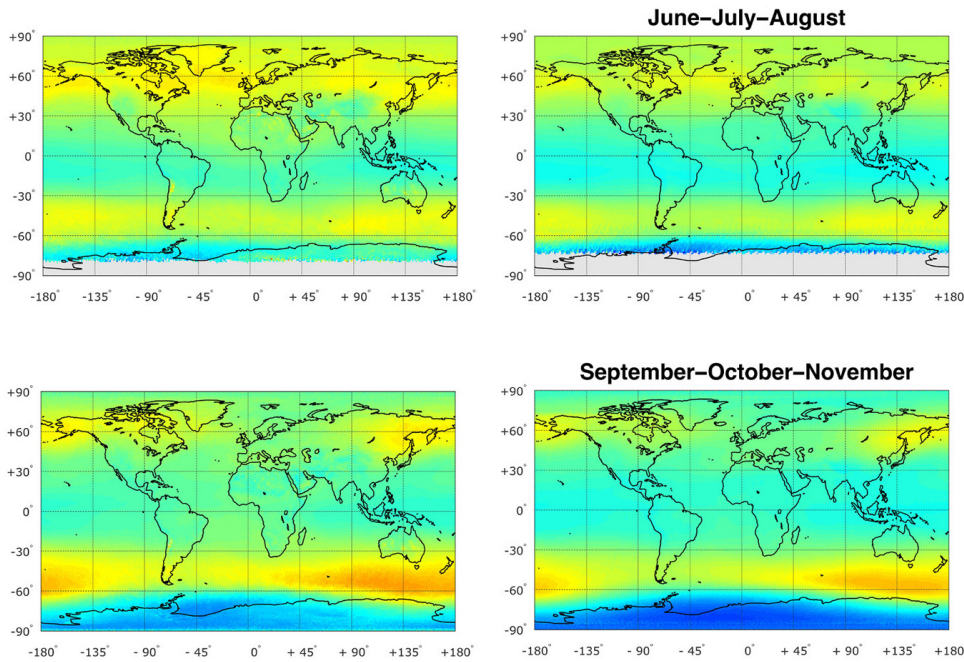

100x(IASI-GOME-2)/GOME-2
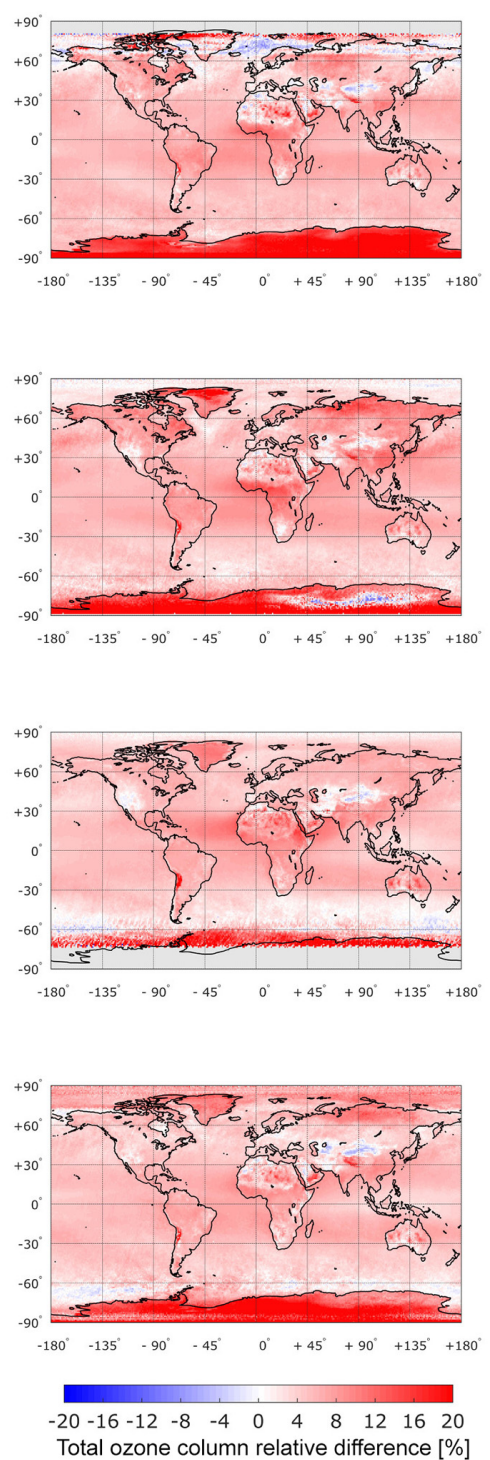

Figure 6. Global distribution for three months averaged periods $\left(1^{\circ} \times 1^{\circ}\right.$ grid) between 2008 and 2014: (left) IASI-A total ozone column compared to (middle) GOME-2A O3M SAF retrieved total ozone columns for daytime observations. The relative differences (in percent) calculated as (IASI-GOME2) / GOME2 $\times 100$ are displayed on the right panels.

calculated spatially across grid locations within a latitude band. Globally, IASI-A and GOME-2A are in good agreement, with coefficients of correlation ranging from 0.93 to 0.98 and a positive bias from IASI-A of 5.5 to $7.1 \%$ depending on the season. On average, over the period 2008-2014, the bias value is around $6.2 \pm 7.5 \%$, which is of the same order as the bias reported in Antón et al. (2011). The detailed analysis undertaken for different latitude bands shows that the highest correlation coefficients are found in the midlatitude regions, with values higher than 0.93 . Poor correlation is found between IASI-A and GOME-2A in the high latitudes of the Southern Hemisphere ( $\mathrm{SH}$ ) during austral summer and fall. However, during the $\mathrm{O}_{3}$ hole season, high correlation of 0.96 is found in the southern polar region, with IASI-A TOCs being positively biased $(\sim 11.6 \%)$. This suggests that IASI underestimates the extent of $\mathrm{O}_{3}$ depletion (i.e., the TOCs in the ozone hole) with respect to GOME-2A.

Although further investigation is needed to understand the reasons of the local discrepancies (e.g., Antarctica, mountains region, desert), the global difference could be attributed to the following:

1. The different observation modes: (i) the ground footprint is different for both instruments $(12 \mathrm{~km}$ diameter at nadir for IASI vs. $40 \times 80 \mathrm{~km}$ for GOME-2), leading to 

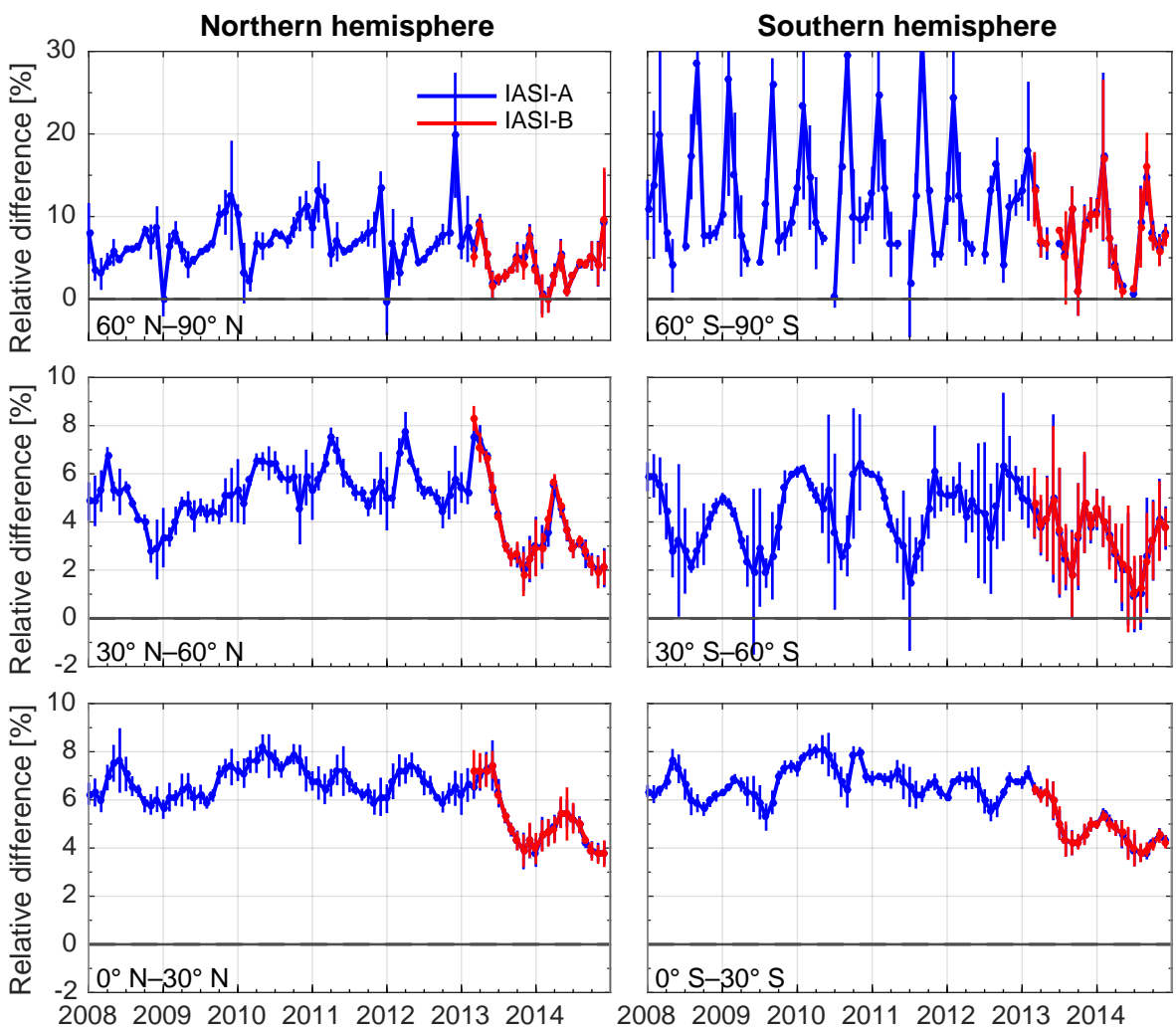

Figure 7. Time series of the monthly relative differences (in percent) between IASI-A (blue) and IASI-B (red) against GOME-2A O3M SAF total ozone columns for different latitudinal bands. The associated standard deviation is also displayed.

Table 2. Summary of the correlation $(R)$, the bias, and the standard deviation of IASI-A total ozone column retrieved from FORLI-O3 v20140922 relative to the O3M SAF GOME-2A retrievals, for each season of the period 2008-2014. The bias and the standard deviation are given in percent. The correlation coefficients higher than 0.85 are indicated in bold.

\begin{tabular}{|c|c|c|c|c|c|c|c|c|}
\hline \multirow[t]{2}{*}{ Latitude range } & \multicolumn{2}{|c|}{ Dec-Jan-Feb } & \multicolumn{2}{|c|}{ Mar-Apr-May } & \multicolumn{2}{|c|}{ Jun-Jul-Aug } & \multicolumn{2}{|c|}{ Sep-Oct-Nov } \\
\hline & $R$ & Bias (\%) & $\mathrm{R}$ & Bias (\%) & $R$ & Bias $(\%)$ & $R$ & Bias $(\%)$ \\
\hline $90^{\circ} \mathrm{S}-90^{\circ} \mathrm{N}$ & 0.93 & $7.1 \pm 7.1$ & 0.95 & $7.0 \pm 76.8$ & 0.95 & $5.5 \pm 4.2$ & 0.98 & $6.4 \pm 4.8$ \\
\hline $60-90^{\circ} \mathrm{N}$ & 0.75 & $4.3 \pm 7.0$ & 0.42 & $5.4 \pm 4.2$ & 0.61 & $4.7 \pm 2.2$ & 0.92 & $6.8 \pm 2.7$ \\
\hline $30-60^{\circ} \mathrm{N}$ & 0.98 & $4.4 \pm 2.5$ & 0.97 & $6.0 \pm 2.3$ & 0.95 & $4.9 \pm 1.8$ & 0.96 & $4.0 \pm 1.9$ \\
\hline $0-30^{\circ} \mathrm{N}$ & 0.88 & $6.1 \pm 2.0$ & 0.93 & $6.7 \pm 12.1$ & 0.87 & $6.6 \pm 2.3$ & 0.79 & $5.9 \pm 1.7$ \\
\hline $0-30^{\circ} \mathrm{S}$ & 0.91 & $6.4 \pm 1.4$ & 0.78 & $6.7 \pm 1.6$ & 0.91 & $5.9 \pm 1.6$ & 0.96 & $5.9 \pm 1.5$ \\
\hline $30-60^{\circ} \mathrm{S}$ & 0.99 & $5.2 \pm 0.8$ & 0.97 & $4.0 \pm 1.0$ & 0.93 & $2.6 \pm 1.9$ & 0.99 & $4.2 \pm 1.2$ \\
\hline $60-90^{\circ} \mathrm{S}$ & 0.26 & $15.6 \pm 12.3$ & 0.25 & $13.5 \pm 14.0$ & 0.88 & $12.3 \pm 10.0$ & 0.96 & $11.6 \pm 9.0$ \\
\hline
\end{tabular}

different cloud contamination; (ii) the atmospheric light paths of the IASI and GOME-2 observations are different (i.e., GOME-2 measures the solar reflected radiation), which implies that different air masses are probed.

2. The $\sim 4 \%$ disagreement between the ozone absorption coefficients in the IR and UV spectral regions (PicquetVarrault et al., 2005; Gratien et al., 2010).

3. The different weighting functions and vertical sensitivities: GOME-2 has a maximum sensitivity in the strato- sphere, while IASI presents a maximum sensitivity in the free troposphere (Boynard et al., 2009).

Possible reasons for the larger discrepancies observed at high latitudes are (i) the limited information content in the IASI observations in these regions due to low brightness temperatures (c.f. Fig. 2 and Table 1), (ii) a misrepresentation of the emissivity above ice surfaces, (iii) the temperature profiles used in FORLI that are less reliable at high latitudes and over elevated terrain as shown in August et al. (2012), and (iv) the errors associated with TOC retrievals in the UV-vis 

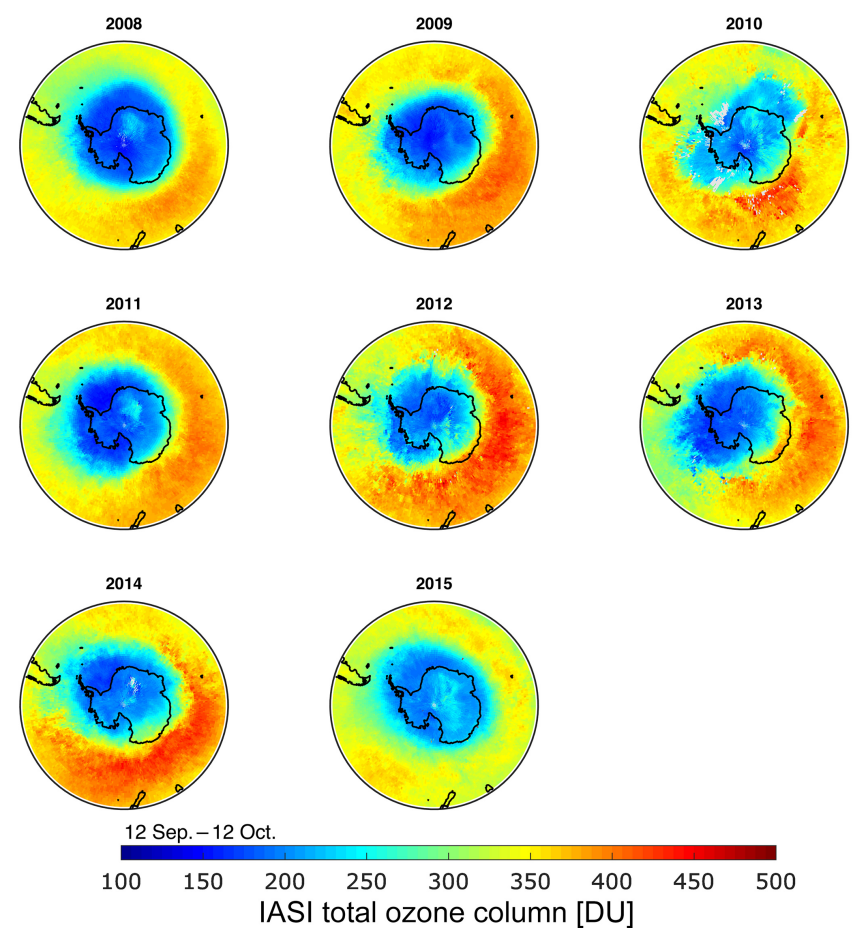

Figure 8. IASI-A total ozone column distribution above Antarctica retrieved using FORLI. Data are averaged over a $1^{\circ} \times 1^{\circ}$ grid and over 1 month from 12 September to 12 October during the period 2008-2015.

spectral range increasing at high solar zenith angles in these regions, mostly because of the larger sensitivity of the retrieval to the a priori $\mathrm{O}_{3}$ profile shape (Lerot et al., 2014). In the tropics, the largest differences are observed above regions characterized by sharp emissivity features, which are misrepresented in FORLI processing. Figure 8 provides an example of $\mathrm{O}_{3}$ monitoring with IASI-A. It illustrates the evolution of $\mathrm{O}_{3}$ hole over 2008-2015, with the distribution of TOCs obtained above Antarctica averaged over 1 month between 12 September and 12 October for each year. This figure highlights the good capability of IASI to capture the spatial and temporal variability of TOCs in the Antarctic region (as already shown in Fig. 6). It is worth noting that the $\mathrm{O}_{3}$ hole size is larger in 2015 than in the previous years (integrated over the same time period) as shown by Fig. 8. According to the World Meteorological Organization (WMO), this larger $\mathrm{O}_{3}$ hole in 2015 is due to unusually cold temperature and weak dynamics in the Antarctic stratosphere. One has to be considerate of the fact that although IASI is able to reproduce the spatiotemporal variability of TOCs, it remains difficult to accurately estimate the Antarctic ozone loss and the size of the ozone hole from IASI data because of large retrieval biases in the region.

\subsection{Comparison with ground-based spectrophotometer data}

Complementary to space observations, total $\mathrm{O}_{3}$ is routinely measured at ground stations by the Brewer and Dobson instruments (Fioletov et al., 2008). These ground-based observations considered as the "ground-truth" standard for TOC measurements are publicly available at the World Ozone and Ultraviolet Radiation Data Centre (WOUDC, http://woudc. org). The total $\mathrm{O}_{3}$ measurement of the Brewer and Dobson instruments relies on the method of differential absorption in the Huggins band where $\mathrm{O}_{3}$ exhibits strong absorption features in the UV part of the solar spectrum. Compared to the Dobson instrument, the Brewer spectrophotometer has an improved optical design and is fully automated. The TOC abundance is determined from a combination of four wavelengths between 306 and $320 \mathrm{~nm}$ with a resolution of $0.6 \mathrm{~nm}$ overcoming the spectral interference of sulfur dioxide with $\mathrm{O}_{3}$ (Kerr et al., 1984; Kerr, 2002). The Dobson and Brewer stations considered in this paper and the criteria used for the selection of the stations have been extensively used in a series of validation papers of satellite total $\mathrm{O}_{3}$ measurements (e.g., Weber et al., 2005; Balis et al., 2007a, b; Koukouli et al., 2012, 2015).

For the comparisons with IASI TOCs from FORLI, only direct sun observations are used as those are the most reliable for both the Dobson and the Brewer spectrophotometers, the latter offering an accuracy of about $1 \%$ at moderate solar zenith angles (e.g., Kerr, 2002). All data available for the period 2008-2014 have been extracted. The data format currently used consists of daily total $\mathrm{O}_{3}$ values expressed in Dobson units (DU). We set the coincidence criteria to a $50 \mathrm{~km}$ search radius between the satellite center of pixel and the geocolocation of the ground-based station as well as to the same day of observations. All IASI TOCs meeting the above criteria were then averaged for each groundbased measurement. In total 47 Brewer and 53 Dobson stations were considered for the comparison. As shown in Fig. 9 illustrating the locations of the stations, a wide geographical region is covered by the network of ground-based instruments, with fair sampling of all latitudes. More specifically, apart from three Antarctic stations, the Brewer network mostly represents the Northern Hemisphere $(\mathrm{NH})$, whereas the Dobson network is more balanced in terms of latitude coverage. Also note that the most represented latitudinal region is that of the northern middle latitudes for both types of instrument. Both IASI-A and IASI-B were compared to the ground-based observations. In order to ensure consistency in the product validation and intercomparison of the different products, the ground-based data set was reduced to contain only the common co-locations between the two space-borne instruments and the respective ground-based one during the period March 2013-December 2014.

Figure 10 shows the relative differences between IASI$A$ in blue and IASI-B in red and the ground-based 

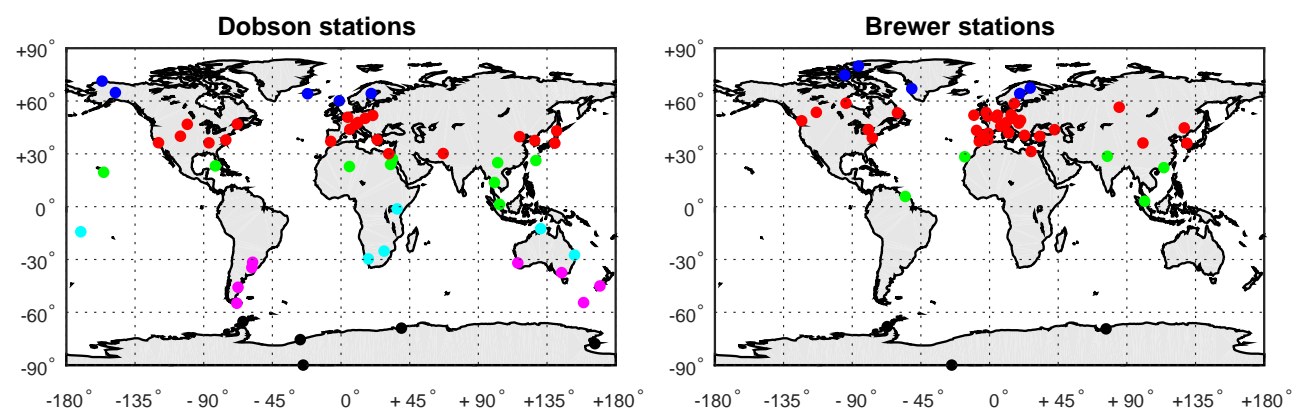

Figure 9. Location of the WOUDC network of ground-based stations used in the present validation exercise; Dobson stations are shown on the left and Brewer stations on the right. The colors indicate different latitude bands: $60-90^{\circ} \mathrm{N}$ (blue), $30-60^{\circ} \mathrm{N}$ (red), $0-30^{\circ} \mathrm{N}$ (green), $0-30^{\circ} \mathrm{S}$ (cyan), 30-60 $\mathrm{S}$ (magenta), and 60-90 $\mathrm{S}$ (black).
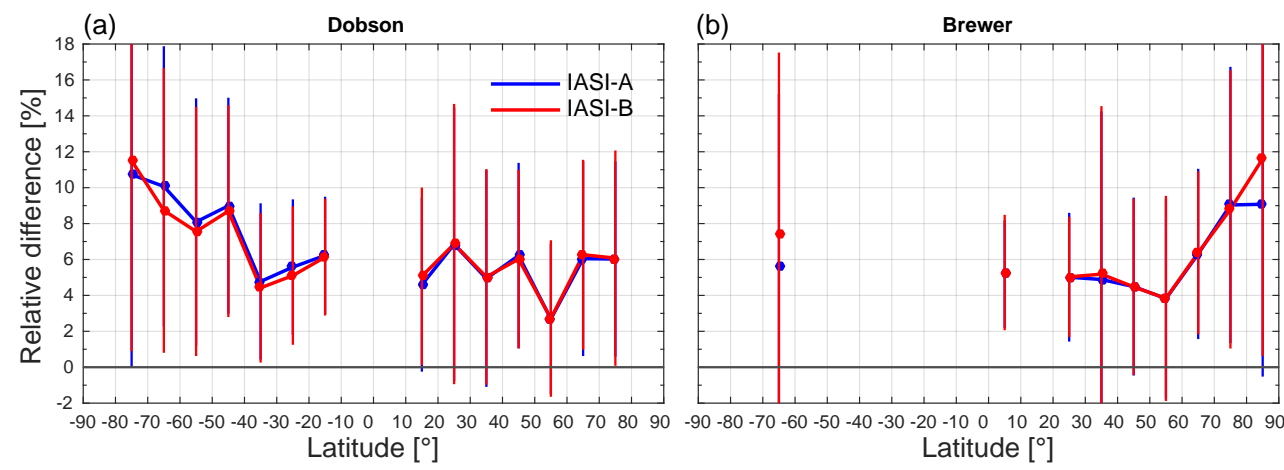

Figure 10. Latitudinal variability of the relative differences (in percent) between IASI-A (blue) and IASI-B (red) against co-located Dobson (a) and Brewer (b) given in bins of $10^{\circ}$. For the period March 2013 onwards, only the common co-locations between the two satellites are shown. The associated standard deviation of the relative differences is also displayed.

TOCs averaged over $10^{\circ}$ latitude bands for the period 2008-2014 and 2013-2014 respectively. For each daily ground-based measurement a relative difference is calculated as $100 \times($ IASI - GROUND-BASED) / GROUND-BASED. All those relative differences are then separated into latitudinal bins and the mean of those is calculated. Very similar features between the IASI-A and IASI-B comparisons can be seen, with the Antarctic being largely overestimated (up to $20 \%$ and beyond) and the northern middle latitudes driving the mean comparisons around the $4 \%$ to $6 \%$ level. Larger differences are also seen in the southern midlatitudes (up to $8 \%$ ) and in the northern high latitudes (up to $9 \%$ ), which is consistent with the results found for the IASI/GOME-2A comparison (c.f. Figs. 6 and 7). Figure 11 shows the time series of monthly mean differences between IASI-A and IASIB against Dobson and Brewer TOCs for the period 20082014 for the NH. For each ground-based measurement, a daily relative difference is calculated. All those relative differences are then monthly averaged. IASI with FORLI processing overestimates total $\mathrm{O}_{3}$ abundance compared to the Dobson and Brewer instruments. The mean difference between IASI and Dobson measurement is $\sim 5 \pm 1 \%$ for the $\mathrm{NH}$, whereas it is slightly larger $(\sim 6 \pm 1 \%)$ for the $\mathrm{SH}$.
A similar picture is revealed by the Brewer network comparisons, with a mean difference between IASI and Brewer TOCs of $\sim 4 \pm 1 \%$. Similar results are found for the comparison between IASI and Dobson in the SH (not shown here). As for the IASI/GOME-2A TOC comparison, an obvious seasonal variability in the difference between IASI and ground-based TOCs is visible with the lowest difference in summer and the largest differences in winter. These results are consistent with those found for the comparison with GOME-2 measurements. The possible reasons of the discrepancies are detailed in Sect. 4.1.

\subsection{Comparison with ground-based $\mathrm{SAOZ}$ data}

The SAOZ is a zenith-sky UV-vis spectrometer developed by Pommereau and Goutail (1988) following the discovery of the $\mathrm{O}_{3}$ hole in Antarctica by Farman et al. (1985). Since the late 1980s, about 20 instruments distributed in latitude have been deployed within the Network for the Detection of Atmospheric Composition Change (NDACC). The SAOZ TOC measurements are performed in the visible Chappuis bands between 450 and $550 \mathrm{~nm}$ with a spectral resolution of $1.0 \mathrm{~nm}$, twice a day, at sunrise and sunset at solar zenith angle between 86 and $91^{\circ}$. The retrieval makes use of the DOAS 

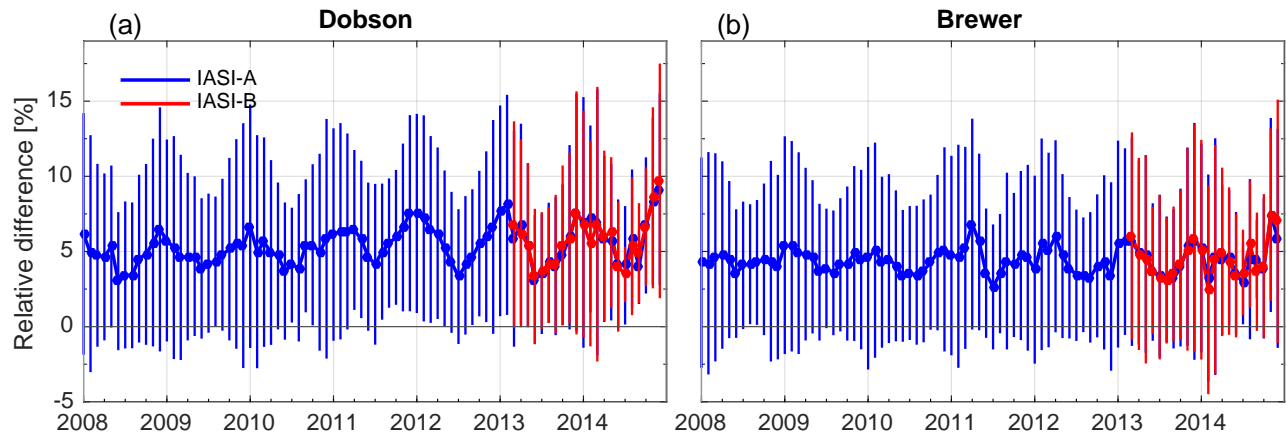

Figure 11. Monthly mean differences (in percent) between IASI-A (blue) and IASI-B (red) TOCs against co-located Dobson (a) and Brewer (b) spectrophotometer TOCs for the Northern Hemisphere. For the period March 2013 onwards, only the common co-locations between the two satellites are shown. The associated standard deviation of the monthly mean relative differences is also displayed.

Table 3. List of the eight SAOZ stations used for the IASI total ozone column validation.

\begin{tabular}{lccr}
\hline Stations & Latitude $\left(^{\circ}\right)$ & Longitude $\left(^{\circ}\right)$ & Altitude $(\mathrm{m})$ \\
\hline Scoresby Sound & 70.5 & -22.0 & 67 \\
Sodankylä & 67.4 & 26.6 & 170 \\
OHP & 43.9 & 5.7 & 683 \\
Reunion & -20.9 & 55.5 & 110 \\
Bauru & -22.3 & -49.0 & 640 \\
Kerguelen & -49.4 & 70.3 & 36 \\
Río Gallegos & -51.6 & -69.3 & 15 \\
Dumont d'Urville & -66.7 & 140.0 & 45 \\
\hline
\end{tabular}

procedure (Platt, 1994). SAOZ performances have been continuously evaluated by regular comparisons with UV-vis independent observations (e.g., Hofmann et al., 1995; Roscoe et al., 1999; Hendrick et al., 2011). The SAOZ precision is $4.7 \%$, while the SAOZ total accuracy is $5.9 \%$ (Hendrick et al., 2011).

In this study, eight SAOZ stations deployed at all latitudes from the Arctic to the Antarctic (see Table 3 for their locations) have been used for IASI TOC validation. Sunrise (sunset) SAOZ measurements are compared to co-located daytime (nighttime) IASI daily data averaged in a $300 \mathrm{~km}$ diameter semicircular area located to the east (west) of the groundbased station. Note that similar results are found for dayand nighttime measurements, so only the results related to daytime data are shown here. In order to ensure consistency in the product validation and intercomparison of the different products, the SAOZ data set was reduced to contain only the common co-locations between the two IASI instruments and the respective SAOZ one during the period March 2013December 2014.

Figure 12 shows the temporal variation of the monthly mean relative differences between IASI-A in blue and IASI-B in red against SAOZ daytime TOCs for the eight SAOZ stations for the period 2008-2014. For each daily $\mathrm{SAOZ}$ measurement, a relative difference is calculated as
Table 4. Mean relative differences and standard deviation (in percent) between IASI-A and SAOZ total ozone for different latitude zones and daytime measurements.

\begin{tabular}{ll}
\hline Latitude band & Bias (\%) \\
\hline $60-70^{\circ} \mathrm{N}$ & $6.8 \pm 2.8$ \\
$30-60^{\circ} \mathrm{N}$ & $3.8 \pm 1.4$ \\
$0-30^{\circ} \mathrm{S}$ & $4.1 \pm 1.2$ \\
$30-60^{\circ} \mathrm{S}$ & $1.6 \pm 1.0$ \\
$60-70^{\circ} \mathrm{S}$ & $7.6 \pm 3.6$ \\
\hline
\end{tabular}

$100 \times($ IASI - SAOZ) $/$ SAOZ. All those relative differences are then monthly averaged. Here we again clearly see the systematic overestimation of IASI TOCs from FORLI and the seasonality in the differences, both of increasing amplitude with latitude. Compared to SAOZ, the IASI TOCs are biased by $2-4 \%(1-2 \%$ monthly mean averaged standard deviation) in the tropics and midlatitudes, and this value is increasing to about $7 \pm 3 \%$ at the polar circle and to 15 $20 \pm 15 \%$ at higher latitude (not shown). Table 4 gives a summary of the statistic by latitude zones. The results are consistent with those found for the comparison with GOME2 along with Brewer and Dobson measurements. In addition to the possible reasons of the discrepancies discussed in Sect. 4.1, the mean biases, which vary also with the station, are attributed to the longitudinal variation of the $\mathrm{O}_{3}$ profile ignored in SAOZ retrievals. In particular, the $4 \%$ bias drop between Reunion and Bauru stations located at the same latitude (see Fig. 12) is attributed to the larger $\mathrm{O}_{3}$ concentration in the upper troposphere above the South American continent in contrast to the Indian Ocean (Pastel et al., 2014).

\section{Validation of IASI ozone vertical profiles}

In situ measurements of vertical $\mathrm{O}_{3}$ profiles are routinely performed from balloon sondes launched at different stations around the world. The sondes provide measurements of $\mathrm{O}_{3}$, 

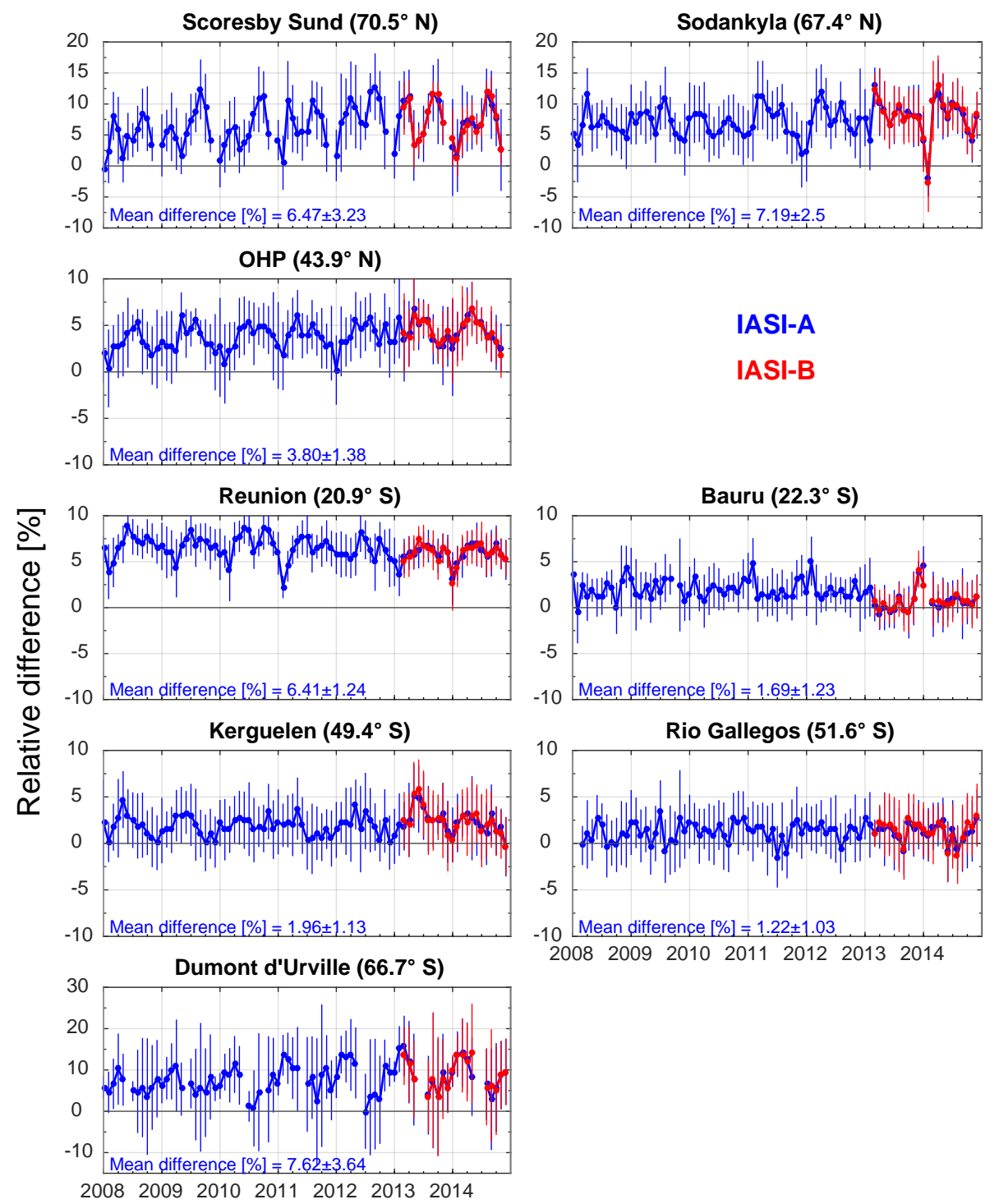

Figure 12. Monthly mean relative differences (in percent) between IASI-A (blue) and IASI-B (red) TOCs against co-located SAOZ TOCs for eight stations from north to south. For the period March 2013 onwards, only the common co-locations between the two satellites are shown. The error bars display the associated monthly mean standard deviation. The 7-year mean relative difference and standard deviation (in percent) are indicated on each panel. The relative difference (in percent) is calculated as $(100 \times(\mathrm{IASI}-\mathrm{SAOZ}) / \mathrm{SAOZ})$.

temperature, pressure, and humidity up to $30-35 \mathrm{~km}$ with a vertical resolution of $\sim 150 \mathrm{~m}$. For the validation of IASI $\mathrm{O}_{3}$ vertical profiles, global profiles measured from 2008 to 2014 and archived at the WOUDC were extracted. Only sonde measurements based on electrochemical concentration cells (ECCs), which measure the oxidation of a potassium iodine (KI) solution by $\mathrm{O}_{3}$ (Komhyr et al., 1995), are used in this study. Their accuracy is generally sufficient $( \pm 5 \%)$ (Deshler et al., 2008; Smit et al., 2007) and they have been widely used before for the validation of satellite $\mathrm{O}_{3}$ profiles (e.g., Nassar et al., 2008; Boynard et al., 2009; Keim et al., 2009; Kroon et al., 2011; Dufour et al., 2012; Verstraten et al., 2013).
We set the coincidence criteria between IASI and the sondes to a $50 \mathrm{~km}$ search radius between the satellite center of pixel and the geocolocation of the ground-based station as well as to a temporal coincidence of $\pm 10 \mathrm{~h}$. We chose these two co-location criteria in order to obtain a sufficient number of data pairs in the tropics and the southern midlatitudes for statistical comparison. Fifty-five ozonesonde stations in midlatitude, polar, and tropical regions were considered for the comparison. Figure 13 (left panel) presents a map of the ozonesonde stations used in the validation exercise, showing that most of sonde stations used in this study are located in the northern midlatitudes. Figure 13 (right panel) shows the distribution of the amount of IASI-ozonesonde coinci- 

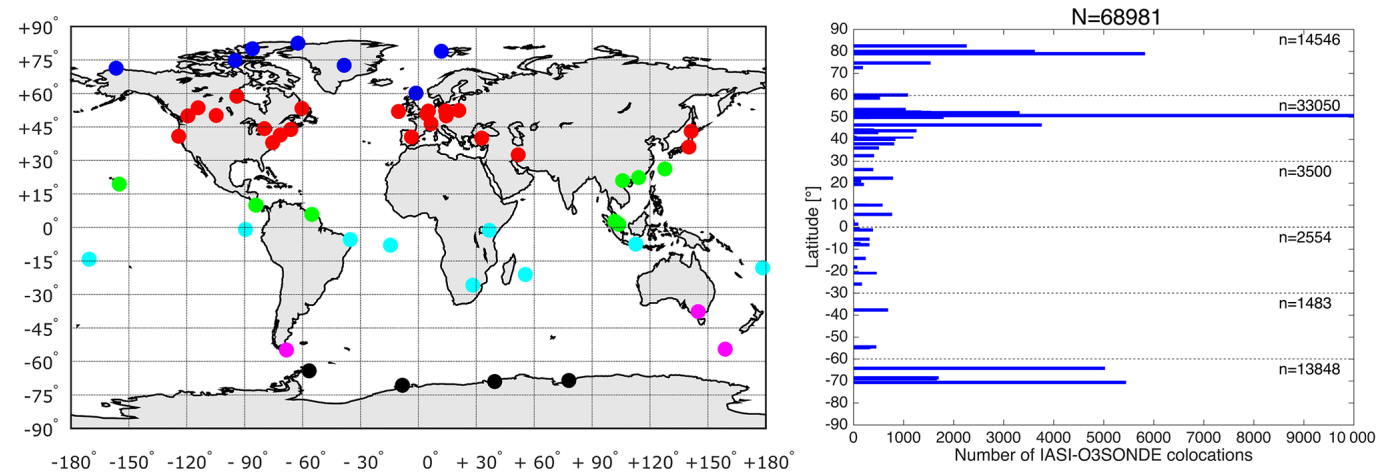

Figure 13. Left: location of the worldwide ozonesonde profiles of WOUDC used in this analysis. The colors indicate different latitude

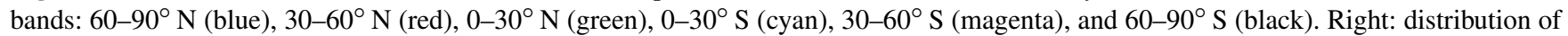
the amount of IASI-A-ozonesonde coincidences available for this study as a function of latitude. The dashed grey lines indicate the latitude boundaries used in this study to evaluate the IASI biases in more detail: the northern high latitude region is at $60-90^{\circ} \mathrm{N}$, the northern middle latitude region is at $30-60^{\circ} \mathrm{N}$, the northern tropics is at $0-30^{\circ} \mathrm{N}$, and the same symmetrically opposite for the Southern Hemisphere.

dences available for this study as a function of latitude. More than 6600 sonde measurements and 68000 coincident clearsky IASI observations during a period extending from January 2008 to December 2014 were found with more than half of them located in the northern midlatitudes.

To allow for a meaningful comparison with the high vertical resolution profiles measured by ozonesondes, the difference in vertical resolution and sensitivity between the two data sets has to be accounted for. The ozonesonde vertical profiles were smoothed according to the IASI averaging kernel and a priori constraints leading to a vertical profile representing what IASI would measure for the same sonde sampled atmospheric air mass. According to Rodgers (2000) the smoothing of the true state can be characterized as follows:

$\boldsymbol{x}_{\mathrm{s}}=\boldsymbol{x}_{\mathrm{a}}+\mathbf{A}\left(\boldsymbol{x}_{\text {sonde }}-\boldsymbol{x}_{\mathrm{a}}\right)$,

where $\boldsymbol{x}_{\mathrm{s}}$ is the smoothed ozonesonde profile, $\boldsymbol{x}_{\text {sonde }}$ is the measured ozonesonde profile, $\boldsymbol{x}_{\mathrm{a}}$ is the a priori profile, and $\mathbf{A}$ the averaging kernel matrix. For each daily raw ozonesonde measurements, all collocated IASI and smoothed sonde profiles are averaged.

Figure 14 shows the comparison between the mean retrieved IASI-A profile with the smoothed and raw ozonesonde profiles for different latitude bands, taking into account all IASI-A-sonde coincidences within the 7-year (2008-2014) period. Looking at the ozone vertical profiles (left panels), we clearly see that IASI is able to capture the main features of the ozonesonde vertical distribution except in the southern high latitudes. Those are (i) the ozone peaks around $20-30 \mathrm{~km}$ depending on the latitude, (ii) a decrease in the ozone maximum altitude increasing with latitude, and (iii) sharp ozone gradients between the troposphere and the vertically stratified lower stratosphere. Another feature that we can see is the northern high and middle ozonesonde profiles exhibiting a small filament, which is also observed by IASI. Although IASI overestimates the ozone peak, it is able to represent the ozone peak altitude and the changes in vertical gradients, which is one of the important characteristics of the successful ozone profile retrieval.

The relative difference $(100 \times($ IASI - sonde $) /$ sonde $)$ between the mean retrieved profile and the smoothed ozonesonde profile is also displayed (right panels). The main features are that IASI generally underestimates $\mathrm{O}_{3}$ in the troposphere (up to $15 \%$ in the midlatitudes) and overestimates $\mathrm{O}_{3}$ in the stratosphere (up to $\sim 35 \%$ in the tropical middle stratosphere). We can notice that for all latitude bands except for the midlatitudes, the bias is larger in the UTLS region, especially in the tropics (up to $\pm 50 \%$ ), which can be partly explained by the low $\mathrm{O}_{3}$ amounts leading to larger relative errors (Wespes et al., 2016). Other possible reasons for the larger bias in the UTLS are the limited IASI vertical resolution, spectroscopic uncertainties on ozone line, or the use of inadequate a priori information. In particular the impact of using a priori constraints varying with latitude and/or month has to be tested yet.

Because of the small number of independent pieces of information retrieved from the profile, which vary between 2 at high latitudes and 4.5 in the tropics (c.f. Fig. 2), in the following we assess ozone partial columns instead of the vertical profile. We divide the altitude range to four vertical layers: surface-300 hPa (troposphere), 300-150 hPa (UTLS), 150$25 \mathrm{hPa}$ (LMS), and 25-3 hPa (MS for middle stratosphere), based on the Wespes et al. (2016) study showing that these columns contain around one piece of information with a maximum sensitivity approximately in the middle of each of the layers and reproduce the well-known cycles related to chemical and dynamical processes characterizing these layers. In the following, as ozonesonde profiles are generally available up to $30 \mathrm{~km}$, the MS column is limited to $10 \mathrm{hPa}$.

Figures 15 and 16 show the time series of the monthly mean relative difference between IASI-A and ozonesonde partial columns for the period 2008-2014 for different zonal 

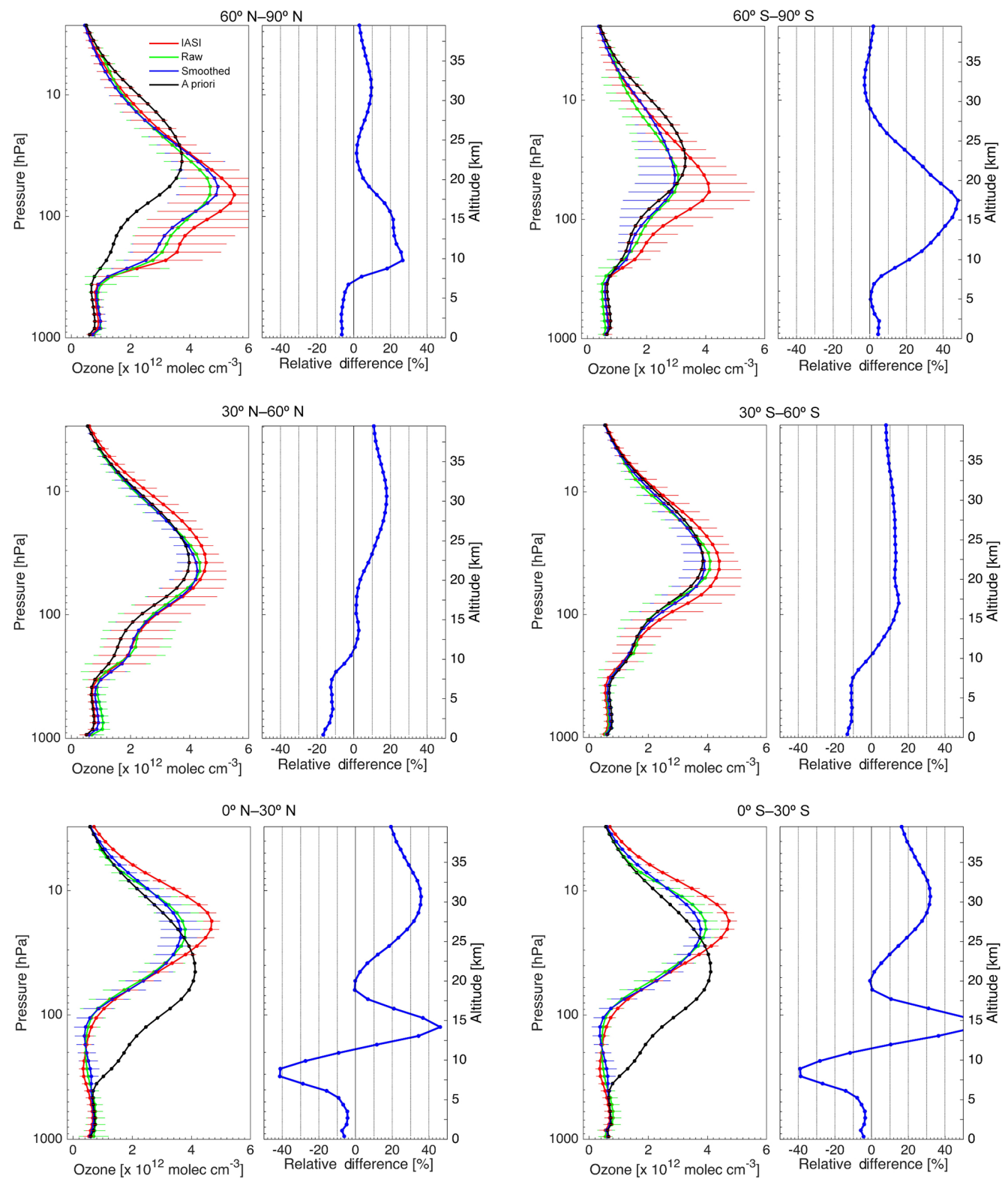

Figure 14. Left panels: mean ozone vertical profiles retrieved by IASI-A (red), observed by the ozonesondes (green), and observed by the ozonesondes after application of the IASI averaging kernels (blue) for $30^{\circ}$ latitude bands. The black line indicates the a priori $\mathrm{O}_{3}$ profiles as used in the IASI retrieval with FORLI. Right panels: vertical profiles of the relative difference (in percent) between the IASI retrieved mean profile and the smoothed ozonesonde mean profile.

bands in the $\mathrm{NH}$ and $\mathrm{SH}$ respectively. The differences between IASI-B and ozonesonde are not included since the number of available ozonesonde measurements is limited in 2014. A main feature that arises from this figure is the pronounced seasonality in the differences between IASI and sonde $\mathrm{O}_{3}$ partial columns at high latitudes (except for the surface- $300 \mathrm{hPa}$ column), with the lowest differences found in summer and the largest differences found in winter. This is due to the large difference in surface temperature (c.f. Table 1) between winter and summer at these latitudes com- pared to the midlatitudes and tropics. We also can see a small but apparent seasonality in the differences for the northern midlatitudes, especially for the $150-25 \mathrm{hPa}$ column. In the high latitudes, the IASI surface- $300 \mathrm{hPa}$ column generally appears little biased with respect to the sondes, compared to the other partial columns. Actually this reflects the low sensitivity of IASI associated with low brightness temperature in the troposphere. As shown in Eq. (1), in such situations, the IASI retrieval mostly provides the a priori information. At high latitudes for both hemispheres, the bias and standard de- 


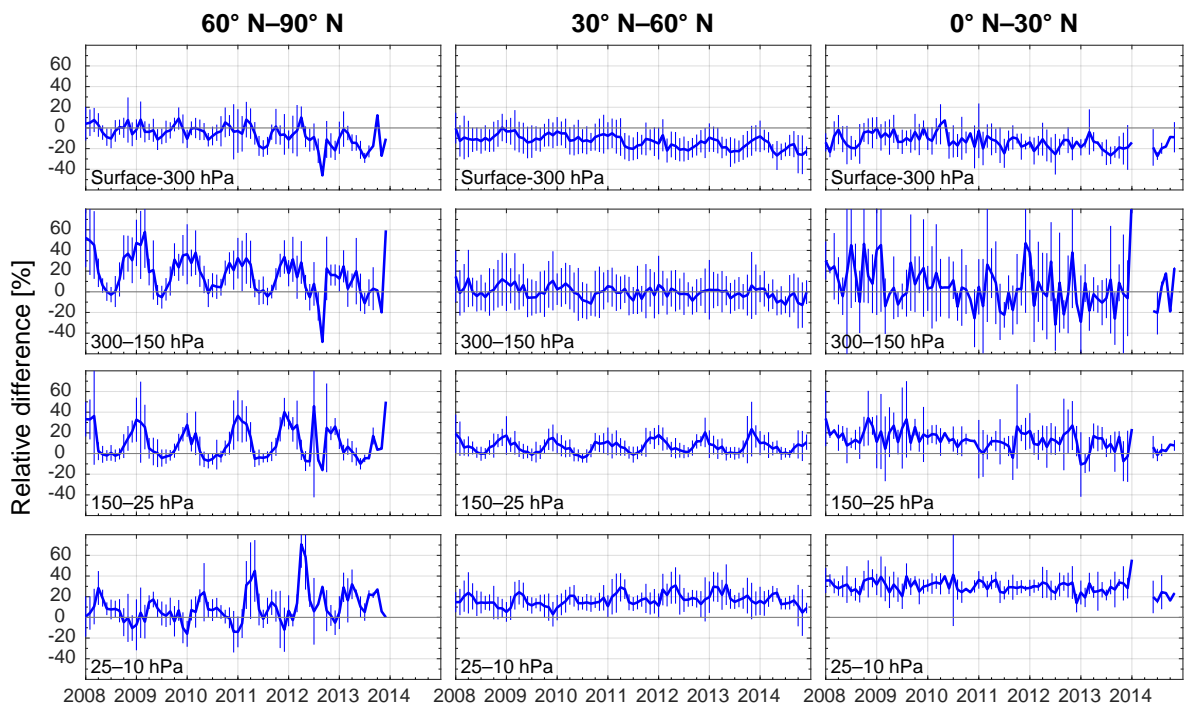

Figure 15. Monthly mean relative differences (in percent) between IASI-A and co-located smoothed ozonesonde for four different partial columns in the Northern Hemisphere: surface-300, 300-150, 150-25, and 25-10 hPa, characterizing the troposphere (TROPO), the upper troposphere and the lower stratosphere (UTLS), the lower/middle stratosphere (LMS), and the middle stratosphere (MS) respectively. The error bars display the associated monthly mean standard deviation. The relative difference (in percent) is calculated as $(100 \times($ IASI - SONDE) $/$ SONDE $)$.

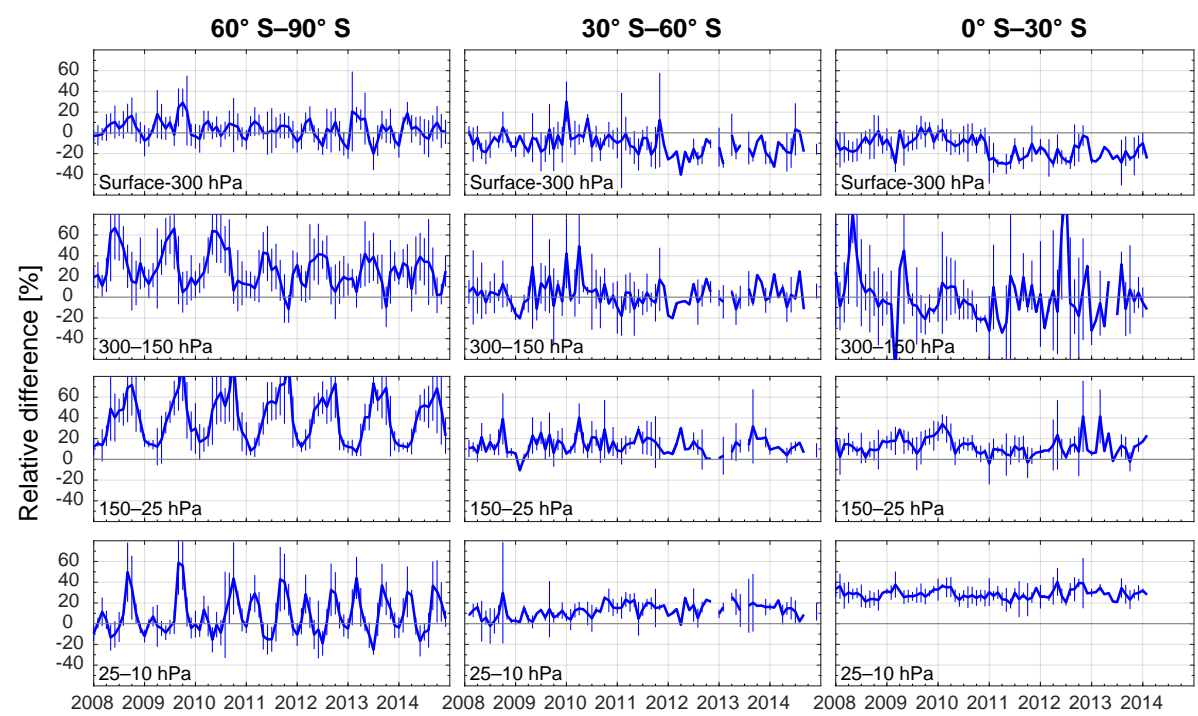

Figure 16. Same as Fig. 15 for the Southern Hemisphere.

viation are larger for the $300-150 \mathrm{hPa}$ column during winter. This may be attributed to the strong variability in $\mathrm{O}_{3}$ in those regions because of stratosphere-troposphere exchange. No seasonal dependency is apparent in the southern midlatitudes and the tropics, which is due to the little seasonal change in surface temperature (c.f. Table 1). The large standard deviations found in the tropics and the southern midlatitudes are due to the limited ozonesonde data (c.f. Fig. 13).

A detailed statistical comparison between IASI and sonde $\mathrm{O}_{3}$ was performed for the four partial columns considered in this study (see Table 5). Globally, IASI is in good agreement with sonde $\mathrm{O}_{3}$ partial columns with correlation coefficients of $0.74-0.89$ and bias ranging from $-10 \%$ in the troposphere to $\sim 14 \%$ in the MS. The best agreement between IASI and sonde $\mathrm{O}_{3}$ is found for the $150-25 \mathrm{hPa}$ partial column with correlation coefficients ranging from 0.76 to 0.88 (except for the tropics). This is due to the fact that there the maximum of $\mathrm{O}_{3}$ is located in this part of the atmosphere. Note that the low bias found in the UTLS region in the middle latitudes and tropics should be treated with caution since IASI is neg- 
Table 5. Overview of the correlation $(R)$, mean relative bias, and associated standard deviation (in percent) between $\mathrm{IASI}_{\text {and }}$ sonde $\mathrm{O}_{3}$ for the period 2008-2014 for different latitude bands and partial columns.

\begin{tabular}{lrr|rr|rr|rr}
\hline \multirow{2}{*}{ Latitude range } & \multicolumn{2}{c|}{ Surface-300 hPa } & \multicolumn{2}{c|}{$300-150 \mathrm{hPa}$} & \multicolumn{2}{c|}{$150-25 \mathrm{hPa}$} & \multicolumn{2}{|c}{$25-10 \mathrm{hPa}$} \\
\cline { 2 - 9 } & $R$ & \multicolumn{1}{c|}{ Bias (\%) } & $R$ & Bias (\%) & $R$ & Bias (\%) & $R$ & Bias (\%) \\
\hline $90^{\circ} \mathrm{S}-90^{\circ} \mathrm{N}$ & 0.74 & $-9.8 \pm 13.5$ & 0.89 & $5.5 \pm 23.1$ & 0.87 & $11.7 \pm 17.1$ & 0.80 & $14.5 \pm 15.2$ \\
$60-90^{\circ} \mathrm{N}$ & 0.77 & $-4.9 \pm 12.1$ & 0.81 & $19.5 \pm 22.6$ & 0.73 & $10.0 \pm 17.0$ & 0.47 & $5.5 \pm 17.8$ \\
$30-60^{\circ} \mathrm{N}$ & 0.67 & $-13.2 \pm 12.3$ & 0.87 & $-1.8 \pm 16.1$ & 0.88 & $4.9 \pm 8.5$ & 0.65 & $15.6 \pm 10.5$ \\
$0-30^{\circ} \mathrm{N}$ & 0.77 & $-14.2 \pm 12.6$ & 0.67 & $6.6 \pm 39.8$ & 0.60 & $11.7 \pm 14.8$ & 0.42 & $29.3 \pm 9.8$ \\
$0-30^{\circ} \mathrm{S}$ & 0.81 & $-12.2 \pm 12.8$ & 0.70 & $3.7 \pm 40.2$ & 0.67 & $11.7 \pm 11.8$ & 0.44 & $27.5 \pm 7.8$ \\
$30-60^{\circ} \mathrm{S}$ & 0.55 & $-12.0 \pm 12.9$ & 0.88 & $0.6 \pm 16.6$ & 0.89 & $13.0 \pm 10.8$ & 0.84 & $12.0 \pm 9.7$ \\
$60-90^{\circ} \mathrm{S}$ & 0.48 & $2.0 \pm 13.3$ & 0.76 & $23.5 \pm 25.1$ & 0.89 & $44.5 \pm 28.0$ & 0.68 & $8.8 \pm 23.8$ \\
\hline
\end{tabular}

atively biased in the upper troposphere and positively biased in the lower stratosphere as shown in Fig. 14. In the LMS and MS, IASI systematically overestimates ozone, with values generally ranging from 5 to $40 \%$. This suggests that the positive bias found for the TOC (c.f. Sect. 4) could be related to biases in the MS where most of $\mathrm{O}_{3}$ is located.

\section{Towards a decrease in the bias}

In order to compute new products related to radiative forcing studies (Doniki et al., 2015), new developments were made in the FORLI-O3 retrieval software. Look-up tables (LUTs) were recalculated to cover a larger spectral range (960$1105 \mathrm{~cm}^{-1}$ ) using the HITRAN 2012 spectroscopic database (Rothman et al., 2013) instead of the HITRAN 2004 database (Rothman et al., 2005) and correcting numerical implementation, especially with regard to the LUTs at higher altitude. Here we assess the new FORLI-O3 retrievals performed for 12 days (the 15th of each month) in 2011. In the following, the updated version of FORLI-O3 is called v20151001, and the relative difference between both versions of FORLI-O3 is calculated as $100 \times(\mathrm{v} 20140922-\mathrm{v} 20151001) / \mathrm{v} 20151001$ (\%). Only common pixels of IASI-A are used for the comparison between the two versions of FORLI-O3.

The current version of the HITRAN database between 960 and $1105 \mathrm{~cm}^{-1}$ includes $52970 \mathrm{O}_{3}$ entries of five isotopologues. The line lists of the two databases HITRAN 2012 and HITRAN 2004 differ by 15 transitions of the very weak hot band $v_{1}+2 v_{2}+v_{3}-2 v_{2}-v_{3}$ in the mentioned above spectral range, where $v_{1}, v_{2}$, and $v_{3}$ are the three vibrational modes of ozone. The line positions and line intensities of all other transitions are identical in both lists. The difference between the two data sets is in the broadening parameters $\left(\gamma_{\text {air }}\right.$ and $\left.\gamma_{\text {self }}\right)$ and in temperature-dependent exponent coefficient $n$ for $\gamma_{\text {air }}$. The actual values of the $\gamma_{\text {air }}, \gamma_{\text {self }}$, and $n$ parameters in the HITRAN 2012 database are based on the results of Wagner et al. (2002).

Figure 17 shows the global relative differences of TOC obtained between FORLI-O3 v20140922 and v20151001 for the 15th of each month of 2011 for daytime and nighttime

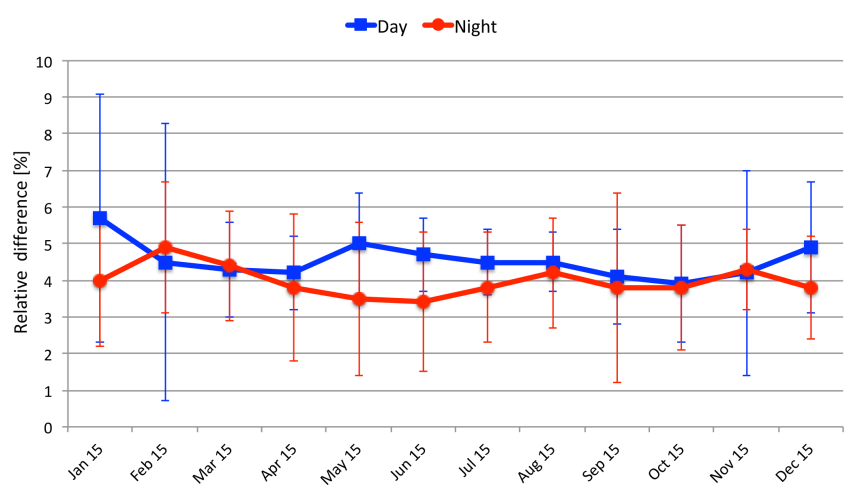

Figure 17. Global daily mean relative differences (in percent) between FORLI v20140922 and FORLI v20151001 total ozone columns for daytime (blue) and nighttime (red) IASI measurements for 12 days in 2011 (on the 15th of each month). The relative difference is calculated as $100 \times(\mathrm{v} 20140922-\mathrm{v} 20151001) / \mathrm{v} 20151001$.

measurements separately. The data were averaged over a $1^{\circ} \times 1^{\circ}$ grid. The relative differences between both versions of FORLI-O3 range between 3 and $6 \%$ depending on month and observation time. With FORLI-O3 v20151001, there is evidence that retrieved total $\mathrm{O}_{3}$ columns are lower by $3-6 \%$ and that this will lead to a marked improvement of the comparison with UV-vis measurements.

In order to investigate the altitude/pressure range impacted by the changes in FORLI-O3, Fig. 18 shows the vertical profiles of relative difference between FORLI-O3 v20140922 and FORLI-O3 v20151001 along with the standard deviation averaged over the 12 days of 2011 for different latitude bands and daytime measurements. FORLI-O3 v20151001 gives lower concentrations of $\mathrm{O}_{3}$ in the MS (above $30 \mathrm{hPa} / 25 \mathrm{~km}$ ) but higher concentrations in UTLS region. In the MS, the differences vary as a function of latitude: the largest differences are found at high latitudes (up to 20\%) and the lowest differences are found in the tropics (less than $10 \%$ ). In the lower troposphere the differences between both versions of FORLI-O3 are smaller $(<5 \%)$. This suggests that 

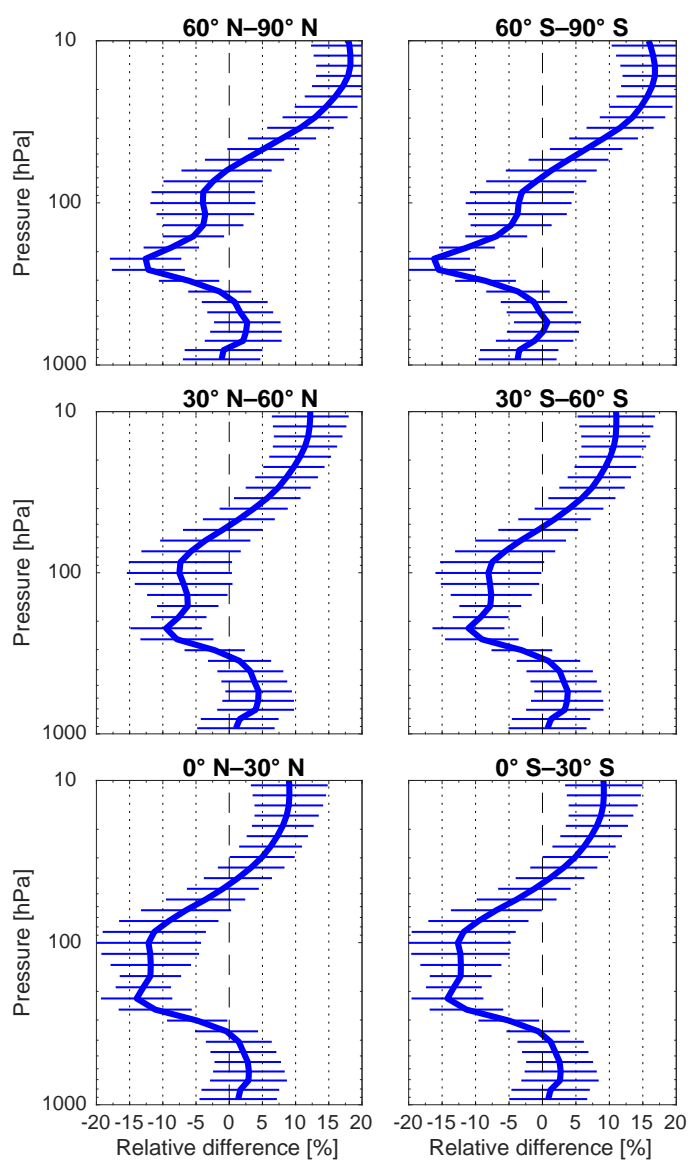

Figure 18. Mean relative differences (in percent) between FORLI v20140922 and FORLI v20151001 averaged over six $30^{\circ}$ latitude bands for daytime measurements. The standard deviation profiles are overlaid. The relative difference is calculated as $100 \times($ v20140922 - v20151001) / v20151001.

the changes made in FORLI v20151001 will impact more the MS where most of $\mathrm{O}_{3}$ is located than the UTLS characterized by lower amount of $\mathrm{O}_{3}$. Similar results are found for nighttime measurements (not shown here).

TOCs obtained from FORLI-O3 v20151001 were compared to GOME-2A data for the 12 days of 2011. Data (daytime only) were averaged over a $1^{\circ} \times 1^{\circ}$ grid. Figure 19 shows the global distribution of the relative difference of TOCs between FORLI-O3 v20140922 (left panel) and v20151001 (right panel) against GOME-2A data. Overall, a much better agreement between IASI-A and GOME-2A is found when FORLI-O3 v20151001 is used although local differences still remain especially in the Antarctic region. The global mean bias found between FORLI-O3 v20140922 and FORLI-I3 v20151001 against and GOME-2A TOCs decreases from $6.5 \pm 7.3$ to $2.1 \pm 9.0 \%$.

We also compared both versions of FORLI-O3 to Brewer and Dobson ground-based measurements. The co-location criteria are the same as that described in Sect. 4.2. Fig- ure 20 shows the latitudinal comparisons between FORLIO3 v20140922 in blue and FORLI-O3 v20151001 in magenta against Brewer, on the right, and Dobson, on the left, TOCs for the 12 days of 2011. The Brewer vs. FORLIO3 v20151001 comparisons revolve around the $0 \%$ difference line for all northern latitudes. The Dobson FORLI-O3 v20151001 comparisons show a peak-to-peak variability between 0 and 4\%, except in the Antarctic region. However, the Antarctic comparisons have also improved in v20151001 with a decrease of the bias from $\sim 18 \%$ to around $\sim 13 \%$. The seasonal dependency and the daily time series (not shown here) also result in a uniform decrease of the differences between IASI and ground-based TOCs. For the 850 Brewer co-locations (located mainly in the $\mathrm{NH}$ ) mean differences decrease from $4.0 \pm 6.5$ to $0.1 \pm 6.6 \%$ while for the 340 common Dobson daily values an improvement from $6.9 \pm 8.6$ to $3.0 \pm 8.5 \%$ is found. The standard deviations remain unchanged between the two versions.

In order to check for improvement in stratosphere retrievals, we finally compared FORLI-O3 v20140922 and v20151001 to ozonesonde vertical profiles smoothed with the IASI averaging kernels. The co-location criterion is the same as that described in Sect. 5; it unfortunately leads to no co-location in the southern midlatitudes. A total of 29 sonde measurements and 449 coincident clear-sky IASI-A observations for the 12 days of 2011 were found in the NH. Figure 21 presents the vertical profiles of the relative differences between FORLI-O3 v20140922 (in blue) and v20151001 (in magenta) against ozonesonde measurements averaged over the 12 days of 2011 for different latitude bands. For all latitudes except the northern high latitudes, we can see an improvement in the MS (above $30 \mathrm{hPa} / 25 \mathrm{~km}$ ) with FORLIO3 v20151001 (the bias decreases by 5-10\% depending on the latitudes). In the UTLS region, the differences between FORLI-O3 v20151001 and sonde $\mathrm{O}_{3}$ concentrations are larger for all latitudes. However, the $\mathrm{O}_{3}$ amount being much lower in the UTLS than in the MS, this does not affect the retrieved total $\mathrm{O}_{3}$ column. No significant changes are found in the troposphere.

These preliminary results show that the improvement in the retrieved IASI TOCs from FORLI v20151001 is mostly related to the improvement in retrieved $\mathrm{O}_{3}$ in the MS above $30 \mathrm{hPa} / 25 \mathrm{~km}$. This is mainly due to the use of updated LUTs calculated over an extended spectral range, with corrections of numerical implementation, especially with regard to the LUTs at higher altitude.

\section{Summary and conclusions}

IASI-A and IASI-B $\mathrm{O}_{3}$ (total and vertical profiles) data retrieved with the FORLI v20140922 software were validated against independent observations during the period 20082014 , on a global scale. For the validation of TOCs, a direct comparison of IASI data with GOME-2, Brewer and Dob- 


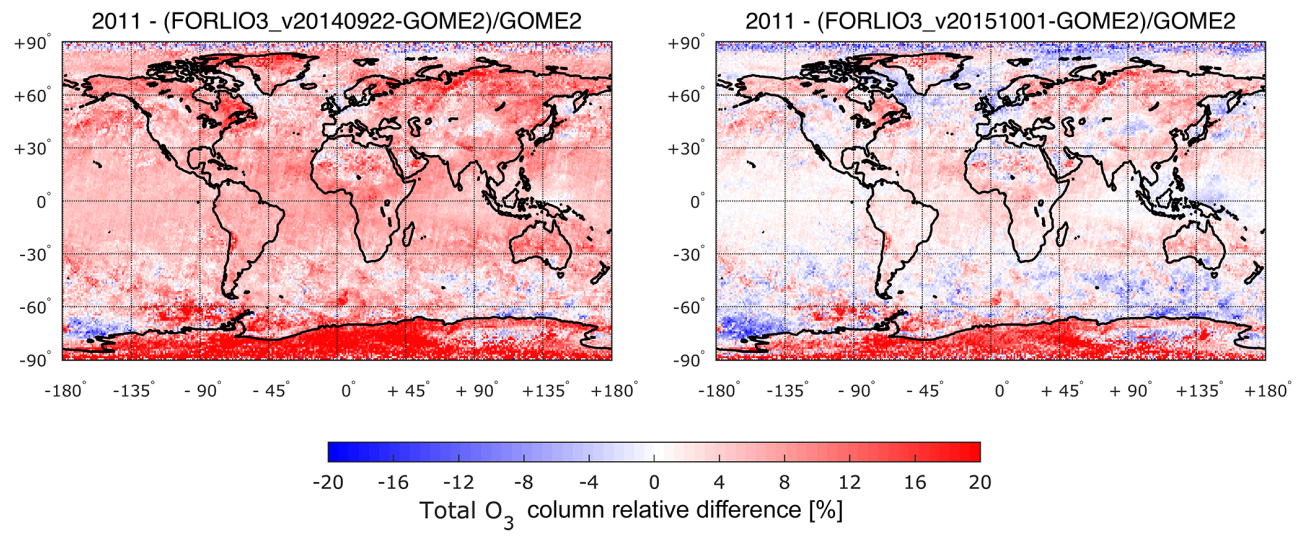

Figure 19. Global distribution of the relative differences (in percent) between FORLI v20140922 (left panel) and FORLI v20151001 (right panel) against GOME-2A O3M SAF TOCs averaged over 12 days of 2011 (on the 15th of each month). The relative difference is calculated as $100 \times($ FORLI-O3 - GOME-2) / GOME-2.
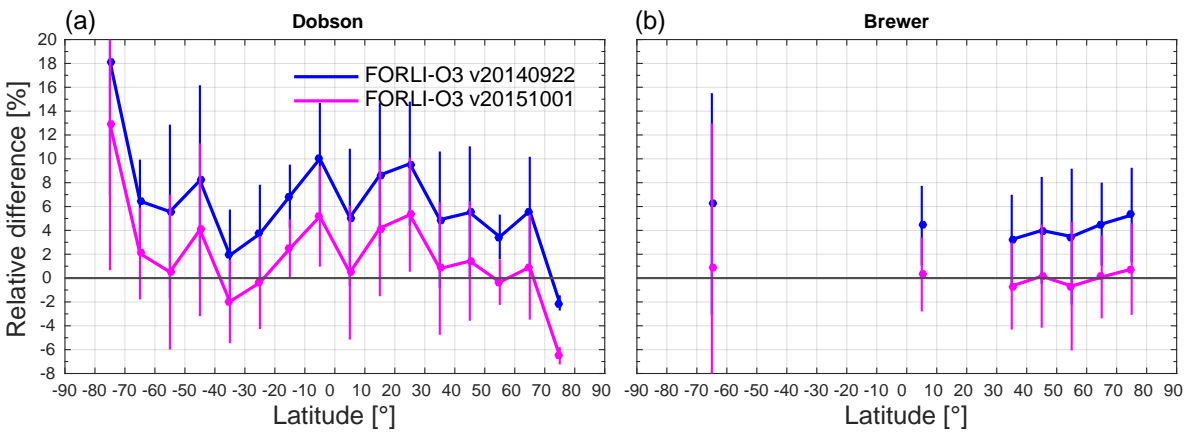

Figure 20. Latitudinal variability of the relative differences (in percent) between FORLI-O3 v20140922 (blue) and FORLI-O3 v20151001 (magenta) against co-located Dobson (a) and Brewer (b) given in bins of $10^{\circ}$. The standard deviation of the relative differences is overlaid. The relative difference is calculated as $100 \times($ FORLI-O3 - ground $) /$ ground.

son spectrophotometers, and $\mathrm{SAOZ}$ spectrometer data was performed. For the validation of $\mathrm{O}_{3}$ vertical profiles against ozonesonde measurements, the ozonesonde vertical profiles were smoothed according to the IASI averaging kernel and a priori constraints, which leads to a vertical profile representing what IASI would measure for the same sonde sampled atmospheric air mass. The main findings of this validation exercise can be summarized as follows:

1. The consistency between IASI-A and IASI-B TOCs (day- and nighttime) has been investigated for the period 2013-2014, and both products are consistent with differences generally less than $1 \%$ irrespective the latitude. A global difference of only $0.2 \pm 0.8 \%$ was found, with IASI-B providing slightly lower values. The comparison between IASI-A and IASI-B $\mathrm{O}_{3}$ vertical profiles showed differences within $2 \%$ for the entire altitude range for all latitudes. IASI-A tends to measure more $\mathrm{O}_{3}$ in the stratosphere and less $\mathrm{O}_{3}$ in the troposphere compared to IASI-B. Both instruments agree best above $20 \mathrm{~km}$, where most of $\mathrm{O}_{3}$ is located (differences less than $0.5 \%)$. In the troposphere, the mean difference between IASI-A and IASI-B $\mathrm{O}_{3}$ is larger $(2.0 \pm 0.2 \%)$. Possible reasons for the differences found are the temporal gap and the different observation geometry (generally off-nadir with opposite angles) leading to different sampling of IASI-A and IASI-B. Larger differences between both IASI sensors are observed over Antarctica with biases more than $-10 \%$ for some seasons in the lower stratosphere. It is likely due to the lower brightness temperature in this region.

2. Globally, IASI with FORLI processing overestimates GOME-2 TOCs by $\sim 6.2 \pm 7.5 \%$, with a clear latitudinal and seasonal dependence. The lowest differences are found in the middle latitudes and the tropics (4$6 \%$ ) while the largest differences are found at high latitudes, especially over Antarctica (11-15\% depending on the season). The comparison with Brewer and Dobson spectrophotometer TOCs shows that a near-constant IASI overestimation of around $5 \%$ is found for all latitudes and for both types of ground-based observations 

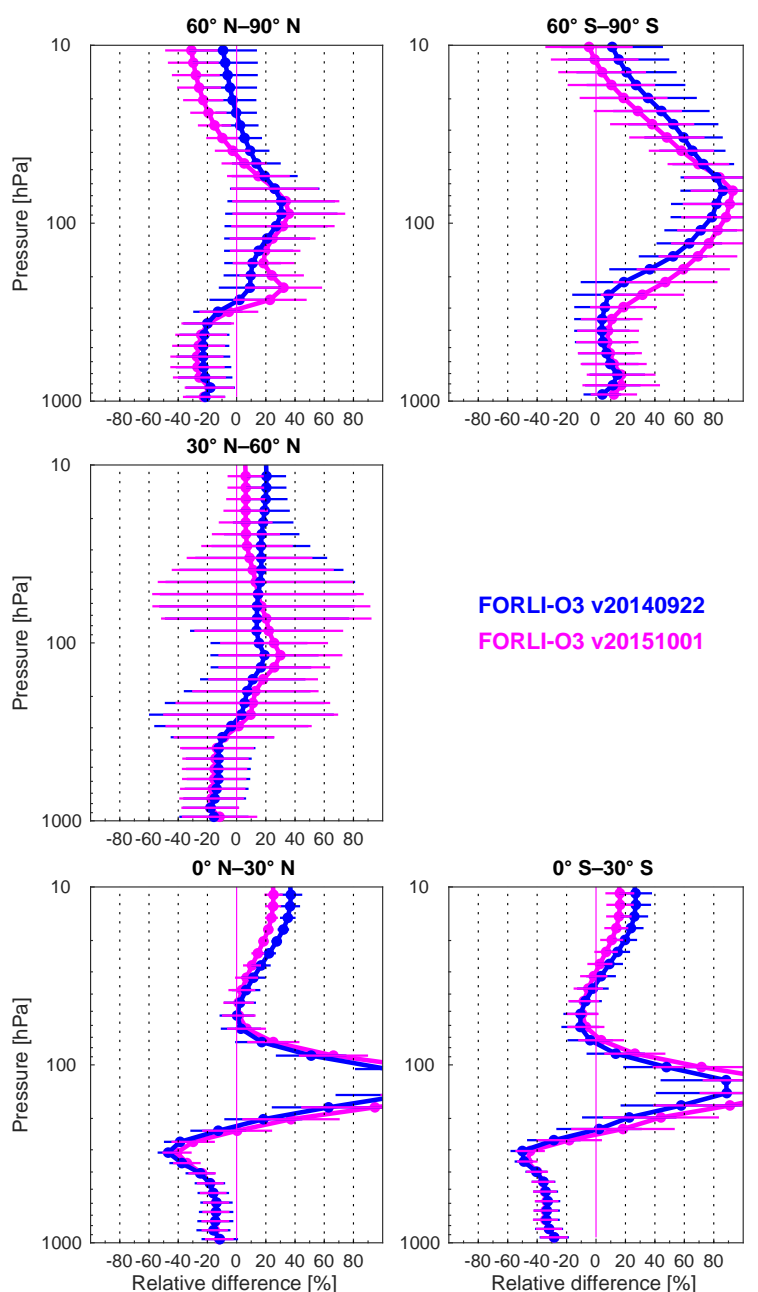

Figure 21. Mean relative differences in percent between FORLIO3 v20140922 (blue) and FORLI-O3 v20151001 (magenta) against sonde ozone vertical profiles for six $30^{\circ}$ latitude bands. The standard deviation profiles are also shown. The relative difference is calculated as $100 \times($ FORLI-O3 - ozonesonde) / ozonesonde.

with the exception of the high latitudes where the difference to both the Dobson and Brewer TOCs rises to 9 and $20 \%$ in the Arctic and Antarctic region respectively. The comparison with SAOZ measurements shows a mean bias between IASI and SAOZ TOCs of $2-4 \%$ in the middle latitudes and tropics and $7 \%$ at the polar circle $\left(60-70^{\circ} \mathrm{N}\right)$.

3. The comparison with ozonesonde vertical profiles shows that the relative differences vary as a function of the altitude. In the troposphere, IASI generally underestimates $\mathrm{O}_{3}$ by up to $15 \%$ except over the Antarctic region. In the LMS, IASI overestimates $\mathrm{O}_{3}$ and the largest differences are found in the tropical tropopause region $(\sim 16 \mathrm{~km})$, which can be explained by the low $\mathrm{O}_{3}$ amounts leading to larger relative error. A statistical analysis performed for four different partial columns characterizing the troposphere, UTLS, LMS, and MS shows globally a good agreement between IASI and sonde $\mathrm{O}_{3}$ partial columns with correlation coefficients of 0.74-0.89 and IASI being negatively biased by $-10 \%$ in the troposphere and positively biased by $\sim 14 \%$ in the MS. A clear positive bias is found for the 25-10 hPa partial column, demonstrating that the systematic positive bias found for the TOCs is related to the bias in the MS, where most of $\mathrm{O}_{3}$ is located.

4. The larger differences found at high latitudes are attributed to reduced IASI sensitivity associated with high latitudes (low brightness temperature) and the temperature profiles used in FORLI that are less reliable in Antarctica. The larger bias found in the UTLS, also found with other TIR sounders (e.g., Nassar et al., 2008; Worden et al., 2007), is not fully understood but some possible explanations are the limited IASI vertical resolution, spectroscopic uncertainties on ozone line, or the use of inadequate a priori information. Further investigations on the retrievals processing need to be performed.

5. The FORLI retrieval software has been updated with LUTs recalculated to cover a larger spectral range (960-1105 $\mathrm{cm}^{-1}$ ) using HITRAN 2012 spectroscopy database instead of HITRAN 2004 and correcting numerical implementation, especially with regard to the LUTs at higher altitude. The assessment of the updated version of FORLI-O3 (v20151001) shows a decrease in the IASI TOC bias by $\sim 4 \%$, bringing the overall global discrepancy to $\sim 1-2 \%$ on average. The comparison between IASI and sonde $\mathrm{O}_{3}$ vertical profiles confirms that the improvement is mainly located in the MS, above $20 \mathrm{~km}$. No significant improvement is found in the UTLS and the troposphere.

The operational IASI $\mathrm{O}_{3}$ products (total and vertical profiles) starting in October 2007 are generated by the LATMOS and ULB in a near-real-time mode. FORLI-O3 v20140922 products are already part of the EUMETSAT's O3M SAF Official Validation Monitoring found at http://lap3.physics. auth.gr/eumetsat/ as part of the operational EUMETSAT services. As FORLI-O3 v20151001 is shown to give a more accurate $\mathrm{O}_{3}$ product than FORLI-O3 v20140922, the data record is currently being back and forward processed for the entire period of IASI (2007-present). The updated FORLI v20151001 will also be implemented into the EUMETSAT processing environment and the new products should be distributed by EUMETCast in 2016. 


\section{Data availability}

The Aeris data infrastructure (http://www.aeris-data.fr; Aeris, 2016) provides the IASI L1C data and L2 temperature data along with the IASI $\mathrm{O}_{3}$ products processed with FORLI-O3 v20151001. The O3M SAF and O3-CCI GOME2 data are available at http://o3msaf.fmi.fi (O3M SAF, 2016) and www.esa-ozone-cci.org (O3-CCI, 2016), respectively. The Brewer, Dobson, and ozonesonde data are available at the WOUDC (http://www.woudc.org; WOUDC, 2016). The SAOZ data are available at http://saoz.obs.uvsq.fr (SAOZ, 2016). The HITRAN spectroscopic database is available at http://hitran.org (HITRAN, 2016). 


\section{Appendix A}

Table A1. List of the 47 Brewer and 53 Dobson quality-assured stations that contribute to the entire validation time period from 2008 to 2014 inclusive.

\begin{tabular}{|c|c|c|c|c|c|}
\hline Brewer station name & Latitude $\left(^{\circ}\right)$ & Longitude $\left({ }^{\circ}\right)$ & Dobson station name & Latitude $\left(^{\circ}\right)$ & Longitude $\left(^{\circ}\right)$ \\
\hline Eureka & 79.89 & -85.93 & Barrow & 71.32 & -156.60 \\
\hline Resolute & 74.72 & -94.98 & Fairbanks & 64.80 & -147.89 \\
\hline Sodankylä & 67.37 & 26.65 & Vindeln & 64.25 & 19.77 \\
\hline Sondrestrom & 67.00 & -50.98 & Reykjavik & 64.13 & -21.90 \\
\hline Vindeln & 64.25 & 19.77 & Lerwick & 60.15 & -1.15 \\
\hline Churchill & 58.75 & -94.07 & Belsk & 51.83 & 20.78 \\
\hline Norrköping & 58.58 & 16.12 & Uccle & 50.80 & 4.35 \\
\hline Tomsk & 56.48 & 84.97 & Hradec Králové & 50.18 & 15.83 \\
\hline Edmonton & 53.57 & -113.52 & Hohenpeissenberg & 47.80 & 11.02 \\
\hline Manchester & 53.45 & -2.26 & Caribou & 46.87 & -68.02 \\
\hline Goose & 53.32 & -60.38 & Arosa & 46.77 & -100.75 \\
\hline Lindenberg & 52.22 & 14.12 & Bismarck & 46.77 & 9.67 \\
\hline Debilt & 52.00 & 5.18 & Haute Provence & 43.92 & 5.75 \\
\hline Valentia & 51.93 & -10.25 & Sapporo & 43.05 & 141.33 \\
\hline Reading & 51.42 & -0.96 & Boulder & 40.02 & -105.25 \\
\hline Uccle & 50.80 & 4.35 & Shiangher & 39.77 & 117.00 \\
\hline Hradec Králové & 50.18 & 15.83 & Athens & 38.00 & 23.70 \\
\hline Poprad-Gánovce & 49.03 & 20.32 & Wallops Island & 37.87 & -75.52 \\
\hline Saturna & 48.78 & -123.13 & Seoul & 37.57 & 126.95 \\
\hline Hohenpeissenberg & 47.80 & 11.02 & El Arenosillo & 37.10 & -6.73 \\
\hline Budapest & 47.43 & 19.18 & Hanford & 36.32 & -119.63 \\
\hline Arosa & 46.77 & 9.67 & Nashville & 36.25 & -86.57 \\
\hline Aosta & 45.71 & 7.33 & Tateno & 36.05 & 140.13 \\
\hline Longfenshan & 44.75 & 127.60 & Quetta & 30.18 & 66.95 \\
\hline Toronto & 43.78 & -79.47 & Cairo & 30.08 & 31.28 \\
\hline Kislovodsk & 43.73 & 42.66 & Hurghada & 27.25 & 33.72 \\
\hline University of Toronto & 43.63 & -79.43 & Naha & 26.20 & 127.67 \\
\hline La Coruna & 43.33 & -8.50 & Kunming & 25.02 & 102.68 \\
\hline Rome University & 41.90 & 12.52 & Aswan & 23.97 & 32.45 \\
\hline Zaragoza & 41.66 & -0.94 & Havana & 23.17 & -82.33 \\
\hline Thessaloniki & 40.52 & 22.97 & Tamanrasset & 22.80 & 5.52 \\
\hline Madrid & 40.45 & -3.55 & Mauna Loa & 19.53 & -155.58 \\
\hline Ankara & 39.95 & 32.88 & Bangkok & 13.73 & 100.57 \\
\hline Goddard & 38.99 & -76.83 & Singapore & 1.33 & 103.88 \\
\hline Murcia & 38.00 & -1.17 & Nairobi & -1.27 & 36.80 \\
\hline El Arenosillo & 37.10 & -6.73 & Darwin & -12.47 & 130.83 \\
\hline Mt. Waliguan & 36.17 & 100.53 & Samoa & -14.25 & -170.57 \\
\hline Pohang & 36.03 & 129.38 & Irene & -25.25 & 28.22 \\
\hline Marsa Matruh & 31.33 & 27.22 & Brisbane & -27.47 & 153.03 \\
\hline New Delhi & 28.63 & 77.22 & Springbok & -29.67 & 17.90 \\
\hline Santa Cruz & 28.35 & -16.29 & Salto & -31.58 & -57.95 \\
\hline Cape D'Aguilar & 22.18 & 114.23 & Perth & -31.95 & 115.85 \\
\hline Paramaribo & 5.78 & -55.20 & Buenos Aires & -34.58 & -58.48 \\
\hline Petaling Jaya & 3.10 & 101.65 & Melbourne & -37.48 & 144.58 \\
\hline San Martin & -68.13 & -67.10 & Lauder & -45.03 & 169.68 \\
\hline Zhongshan & -69.40 & 76.35 & Comodoro Rivadavia & -45.78 & -67.50 \\
\hline \multirow[t]{7}{*}{ Amundsen-Scott } & -89.98 & -24.80 & Macquarie Island & -54.48 & 158.97 \\
\hline & & & Ushuaia & -54.85 & -68.31 \\
\hline & & & Vernadsk-Faraday & -65.25 & -64.27 \\
\hline & & & Syowa & -69.00 & 39.58 \\
\hline & & & Halley Bay & -75.52 & -26.73 \\
\hline & & & Arrival Heights & -77.83 & 166.40 \\
\hline & & & Amundsen-Scott & -89.98 & -24.80 \\
\hline
\end{tabular}


Acknowledgements. IASI is a joint mission of EUMETSAT and the Centre National d'Etudes Spatiales (CNES, France). The IASI L1C data are distributed in near real time by EUMETSAT through the EUMETCast system distribution. The authors acknowledge the Aeris data infrastructure for providing access to the IASI L1C data and L2 temperature data used in this study. This work was undertaken in the framework of the EUMETSAT O3M-SAF project (http://o3msaf.fmi.fi), the European Space Agency O3 Climate Change Initiative (O3-CCI, www.esa-ozone-cci.org), and the EU-FP7 PANDA project (http://www.marcopolo-panda.eu/). The French scientists are grateful to CNES and Centre National de la Recherche Scientifique (CNRS) for financial support. We acknowledge the World Ozone and Ultraviolet Data Centre (WOUDC, http://woudc.org) for providing $\mathrm{O}_{3}$ ground-based and ozonesonde data sets. The research in Belgium is funded by the Belgian State Federal Office for Scientific, Technical and Cultural Affairs and the European Space Agency (ESA Prodex IASI.Flow project). The authors acknowledge the European Communities, the Région Réunion, CNRS, and Université de la Réunion for their support and contribution in the construction phase of the research infrastructure OPAR (Observatoire de Physique de 1'Atmosphère à La Réunion). OPAR is presently funded by CNRS (INSU) and Université de La Réunion and managed by OSU-R (Observatoire des Sciences de l'Univers à La Réunion, UMS 3365). Françoise Posny, Thierry Portafaix (LACy - UMR 8105), and Jean-Marc Metzger (UMS 3365) are also acknowledged for their management, scientific follow-up and technical handling of the SAOZ and ECC observations at La Réunion. Semen Mikhailenko activity was also partly supported by Ural Federal University in the frame of Act 211, contract no. 02.A03.21.0006 and by CNRS (France) and RFBR (Russia) in the frame of the International Associated Laboratory SAMIA.

Edited by: L. Lamsal

Reviewed by: three anonymous referees

\section{References}

Antón, M., Loyola, D., Clerbaux, C., López, M., Vilaplana, J. M., Bañón, M., Hadji-Lazaro, J., Valks, P., Hao, N., Zimmer, W., Coheur, P. F., Hurtmans, D., and Alados-Arboledas, L.: Validation of the MetOp-A total ozone data from GOME-2 and IASI using reference ground-based measurements at the Iberian Peninsula, Remote Sens. Environ., 115, 1380-1386, 2011.

Aeris: IASI L1C data and L2 temperature data along with $\mathrm{IASI} \mathrm{O}_{3}$ products processed with FORLI-O3 v20151001, Institut Pierre Simon Laplace (France), Centre National de la Recherche Scientifique (CNRS, France), Centre National d'Etudes Spatiales (CNES), available at: http://www.aeris-data.fr, last access: 31 August 2016.

August, T., Klaes, D., Schlüssel, P., Hultberg, T., Crapeau, M., Arriaga, A., O'Carroll, A., Coppens, D., Munro, R., and Calbet, X.: IASI on Metop-A: Operational Level 2 retrievals after five years in orbit, J. Quant. Spectrosc. Ra., 113, 1340-1371, doi:10.1016/j.jqsrt.2012.02.028, 2012.

Balis, D., Kroon, M., Koukouli, M. E., Labow, G., Veefkind, J. P., and McPeters, R. D.: Validation of Ozone Monitoring Instrument total ozone column measurements using Brewer and Dob- son spectrophotometer ground based observations, J. Geophys. Res., 112, D24S46, doi:10.1029/2007JD008796, 2007a.

Balis, D., Lambert, J.-C., Van Roozendael, M., Spurr, R., Loyola, D., Livschitz, Y., Valks, P., Amiridis, V., Gerard, P., Granville, J., and Zehner, C.: Ten years of GOME/ERS2 total ozone data the new GOME data processor (GDP) version 4: 2. Groundbased validation and comparisons with TOMS V7/V8, J. Geophys. Res., 112, D07307, doi:10.1029/2005JD00637, 2007b.

Boynard, A., Clerbaux, C., Coheur, P.-F., Hurtmans, D., Turquety, S., George, M., Hadji-Lazaro, J., Keim, C., and MeyerArnek, J.: Measurements of total and tropospheric ozone from IASI: comparison with correlative satellite, ground-based and ozonesonde observations, Atmos. Chem. Phys., 9, 6255-6271, doi:10.5194/acp-9-6255-2009, 2009.

Boynard, B., Clerbaux, C., Clarisse, L., Safieddine, S., Pommier, M., van Damme, M., Bauduin, S., Oudot, C., Hadji-Lazaro, J., Hurtmans, D., and Coheur, P-F.: First simultaneous space measurements of atmospheric pollutants in the boundary layer from IASI: a case study in the North China Plain. Geophys. Res. Lett., 41, 645-651, doi:10.1002/2013GL058333, 2014.

Brunekreef, B. and Holgate, S. T.: Air pollution and health, Lancet, 360, 1233-1242, doi:10.1016/S0140-6736(02)11274-8, 2002.

Chameides, W. L. and Walker, J. C. G.: A photochemical theory for tropospheric ozone, J. Geophys. Res., 78, 8751-8760, 1973.

Clerbaux, C., Boynard, A., Clarisse, L., George, M., Hadji-Lazaro, J., Herbin, H., Hurtmans, D., Pommier, M., Razavi, A., Turquety, S., Wespes, C., and Coheur, P.-F.: Monitoring of atmospheric composition using the thermal infrared IASI/MetOp sounder, Atmos. Chem. Phys., 9, 6041-6054, doi:10.5194/acp-9-6041-2009, 2009.

Clerbaux, C., Hadji-Lazaro, J., Turquety, S., George, M., Boynard, A., Pommier, M., Safieddine, S. Coheur, P.-F., Hurtmans, D., Clarisse, L., and Van Damme, M., Tracking pollutants from space: Eight years of IASI satellite observation, C. R. Geosci., doi:10.1016/j.crte.2015.06.001, 2015.

Crutzen, P. J.: Photochemical reactions initiated by and influencing ozone in the unpolluted troposphere, Tellus, 26, 47-57, 1973.

Deshler, T., Mercer, J. L., Smit, H. G. J., Stubi, R., Levrat, G., Johnson, B. J., Oltmans, S. J., Kivi, R., Thompson, A. M., Witte, J., Davies, J., Schmidlin, F. J., Brothers, G., and Sasaki, T.: Atmospheric comparison of electrochemical cell ozonesondes from different manufacturers, and with different cathode solution strengths: The Balloon Experiment on Standards for Ozonesondes, J. Geophys. Res., 113, D04307, doi:10.1029/2007JD008975, 2008.

Dessler, A.: Chemistry and Physics of Stratospheric Ozone, International Geophysics Series, vol. 74, Academic Press, London, San Diego, 2000.

Doniki, S., Hurtmans, D., Clarisse, L., Clerbaux, C., Worden, H. M., Bowman, K. W., and Coheur, P.-F.: Instantaneous longwave radiative impact of ozone: an application on IASI/MetOp observations, Atmos. Chem. Phys., 15, 12971-12987, doi:10.5194/acp15-12971-2015, 2015.

Dufour, G., Eremenko, M., Orphal, J., and Flaud, J.-M.: IASI observations of seasonal and day-to-day variations of tropospheric ozone over three highly populated areas of China: Beijing, Shanghai, and Hong Kong, Atmos. Chem. Phys., 10, 37873801, doi:10.5194/acp-10-3787-2010, 2010. 
Dufour, G., Eremenko, M., Griesfeller, A., Barret, B., LeFlochmoën, E., Clerbaux, C., Hadji-Lazaro, J., Coheur, P.-F., and Hurtmans, D.: Validation of three different scientific ozone products retrieved from IASI spectra using ozonesondes, Atmos. Meas. Tech., 5, 611-630, doi:10.5194/amt-5-611-2012, 2012.

Dufour, G., Eremenko, M., Cuesta, J., Doche, C., Foret, G., Beekmann, M., Cheiney, A., Wang, Y., Cai, Z., Liu, Y., Takigawa, M., Kanaya, Y., and Flaud, J.-M.: Springtime daily variations in lower-tropospheric ozone over east Asia: the role of cyclonic activity and pollution as observed from space with IASI, Atmos. Chem. Phys., 15, 10839-10856, doi:10.5194/acp-1510839-2015, 2015

Eremenko, M., Dufour, G., Foret, G., Keim, C., Orphal, J., Beekmann, M., Bergametti, G., and Flaud, J.-M.: Tropospheric ozone distributions over Europe during the heat wave in July 2007 observed from infrared nadir spectra recorded by IASI, Geophys. Res. Lett., 35, L18805, doi:10.1029/2008GL034803, 2008.

Farman, J. C., Gardiner, B. G., and Shanklin, J. D.: Large losses of total ozone in Antarctica reveal seasonal $\mathrm{ClOx} / \mathrm{NOx}$ interaction, Nature, 315, 207-210, 1985.

Fioletov, V. E., Labow, G., Evans, R., Hare, E. W., Köhler, U., McElroy, C. T., Miyagawa, K., Redondas, A., Savastiouk,V., Shalamyansky, A. M., Staehelin, J., Vanicek, K., and Weber, M.: The performance of the ground-based total ozone network assessed using satellite data, J. Geophys. Res., 113, D14313, doi:10.1029/2008JD009809, 2008.

Fiore, A. M., Jacob, D. J., Bey, I., Yantosca, R. M., Field, B. D., Fusco, A. C., and Wilkinson, J. G.: Background ozone over the United States in summer: Origin, trend, and contribution to pollution episodes, J. Geophys. Res., 107, 4275, doi:10.1029/2001JD000982, 2002.

Fishman, J. and Larsen, J. C.: Distribution of total ozone and stratospheric ozone in the tropics: Implications for the distribution of tropospheric ozone, J. Geophys. Res., 92, 6627-6634, 1987.

Fishman, J., Watson, C. E., Larsen, J. C., and Logan, J. A.: Distribution of tropospheric ozone determined from satellite data, J. Geophys. Res., 95, 3599-3617, 1990.

Fowler, D., Pilegaard, K., Sutton, M. A., Ambus, P., Raivonen, M., Duyzer, J., Simpson, D., Fagerli, H., Fuzzi, S., Schjoerring, J. K., Granier, C., Neftel, A., Isaksen, I. S. A., Laj, P., Maione, M., Monks, P. S., Burkhardt, J., Daemmgen, U., Neirynck, J., Personne, E., Wichink-Kruit, R., Butterbach-Bahl, K., Flechard, C., Tuovinen, J. P., Coyle, M., Gerosa, G., Loubet, B., Altimir, N., Gruenhage, L., Ammann, C., Cieslik, S., Paoletti, E., Mikkelsen, T. N., Ro-Poulsen, H., Cellier, P., Cape, J. N., Horvath, L., Loreto, F., Niinemets, Ü., Palmer, P. I., Rinne, J., Misztal, P., Nemitz, E., Nilsson, D., Pryor, S.C., Gallagher, M.W., Vesala, T., Skiba, U., Brüggemann, N., Zechmeister-Boltenstern, S., Williams, J., O'Dowd, C., Facchini, M. C., de Leeuw, G., Flossman, A., Chaumerliac, N., and Erisman, J. W.: Atmospheric composition change: Ecosystems-Atmosphere interactions, Atmos. Environ., 43, 5193-5267, doi:10.1016/j.atmosenv.2009.07.068, 2009.

Gazeaux, J., Clerbaux, C., George, M., Hadji-Lazaro, J., Kuttippurath, J., Coheur, P.-F., Hurtmans, D., Deshler, T., Kovilakam, M., Campbell, P., Guidard, V., Rabier, F., and Thépaut, J.-N.: Intercomparison of polar ozone profiles by IASI/MetOp sounder with
2010 Concordiasi ozonesonde observations, Atmos. Meas. Tech., 6, 613-620, doi:10.5194/amt-6-613-2013, 2013.

Gratien, A., Picquet-Varrault, B., Orphal, J., Doussin, J.-F., and Flaud, J.-M.: New Laboratory Intercomparison of the Ozone Absorption Coefficients in the Mid-infrared $(10 \mu \mathrm{m})$ and Ultraviolet (300-350 nm) Spectral Regions, Phys. Chem. A, 114, 1004510048, 2010.

Hao, N., Koukouli, M. E., Inness, A., Valks, P., Loyola, D. G., Zimmer, W., Balis, D. S., Zyrichidou, I., Van Roozendael, M., Lerot, C., and Spurr, R. J. D.: GOME-2 total ozone columns from MetOp-A/MetOp-B and assimilation in the MACC system, Atmos. Meas. Tech., 7, 2937-2951, doi:10.5194/amt-7-2937-2014, 2014.

Hassinen, S., Balis, D., Bauer, H., Begoin, M., Delcloo, A., Eleftheratos, K., Gimeno Garcia, S., Granville, J., Grossi, M., Hao, N., Hedelt, P., Hendrick, F., Hess, M., Heue, K.-P., Hovila, J., JønchSørensen, H., Kalakoski, N., Kauppi, A., Kiemle, S., Kins, L., Koukouli, M. E., Kujanpää, J., Lambert, J.-C., Lang, R., Lerot, C., Loyola, D., Pedergnana, M., Pinardi, G., Romahn, F., van Roozendael, M., Lutz, R., De Smedt, I., Stammes, P., Steinbrecht, W., Tamminen, J., Theys, N., Tilstra, L. G., Tuinder, O. N. E., Valks, P., Zerefos, C., Zimmer, W., and Zyrichidou, I.: Overview of the O3M SAF GOME-2 operational atmospheric composition and UV radiation data products and data availability, Atmos. Meas. Tech., 9, 383-407, doi:10.5194/amt-9-3832016, 2016.

Hendrick, F., Pommereau, J.-P., Goutail, F., Evans, R. D., Ionov, D., Pazmino, A., Kyrö, E., Held, G., Eriksen, P., Dorokhov, V., Gil, M., and Van Roozendael, M.: NDACC/SAOZ UV-visible total ozone measurements: improved retrieval and comparison with correlative ground-based and satellite observations, Atmos. Chem. Phys., 11, 5975-5995, doi:10.5194/acp-11-5975-2011, 2011.

HITRAN: spectroscopic data, available at: http://hitran.org, last access: 31 August 2016.

Hofmann, D., Bonasoni, P., De Maziere, M., Evangelisti, F., Giovanelli, G., Goldman, A., Goutail, F., Harder, J., Jakoubek, R., Johnston, P., Kerr, J., W. Matthews, W. A., McElroy, T., McKenzie, R., Mount, G., Platt, U., Pommereau, J.-P., Sarkissian, A., Simon, P., Solomon, S., Stutz, J., Thomas, A., Van Roozendael, M., and Wu, E.: Intercomparison of UV/visible spectrometers for measurements of stratospheric $\mathrm{NO}_{2}$ for the Network for the Detection of Stratospheric Change, J. Geophys. Res., 100, 1676516791, 1995.

Holton, J. R., Haynes, P. H., McIntyre, M. E., Douglass, A. R., Rood, R. B., and Pfister, L.: Stratosphere-troposphere exchange. Rev. Geophys., 33, 403-439, 1995.

HTAP, UNECE: Hemispheric Transport of Air Pollution 2010: Part A: Ozone and Particulate Matter, Air Pollution Studies No. 17, edited by: Dentener, F., Keating, T., and Akimoto, H., ECE/EN.Air/100, ISSN: 1014-4625, ISBN-13: 978-92-1117043-6, 2010.

Hurtmans, D., Coheur, P.-F., Wespes, C., Clarisse, L., Scharf, O., Clerbaux, C., Hadji-Lazaro, J., George, M., and Turquety, S.: FORLI radiative transfer and retrieval code for IASI, J. Quant. Spectrosc. Ra., 113, 1391-1408, doi:10.1016/j.jqsrt.2012.02.036, 2012.

IPCC: Climate Change 2013: The Physical Science Basis. Contribution of Working Group I to the Fifth Assessment Report of the 
Intergovernmental Panel on Climate Change, edited by: Stocker, T. F., Qin, D., Plattner, G.-K., Tignor, M., Allen, S. K., Boschung, J., Nauels, A., Xia, Y., Bex, V., and Midgley, P. M., Cambridge University Press, Cambridge, United Kingdom and New York, NY, USA, 1535 pp., 2013.

Jones, D. B. A., Bowman, K. W., Horowitz, L. W., Thompson, A. M., Tarasick, D. W., and Witte, J. C.: Estimating the summertime tropospheric ozone distribution over North America through assimilation of observations from the Tropospheric Emission Spectrometer, J. Geophys. Res., 113, D18307, doi:10.1029/2007JD009341, 2008.

Keim, C., Eremenko, M., Orphal, J., Dufour, G., Flaud, J.-M., Höpfner, M., Boynard, A., Clerbaux, C., Payan, S., Coheur, P.-F., Hurtmans, D., Claude, H., Dier, H., Johnson, B., Kelder, H., Kivi, R., Koide, T., López Bartolomé, M., Lambkin, K., Moore, D., Schmidlin, F. J., and Stübi, R.: Tropospheric ozone from IASI: comparison of different inversion algorithms and validation with ozone sondes in the northern middle latitudes, Atmos. Chem. Phys., 9, 9329-9347, doi:10.5194/acp-9-9329-2009, 2009.

Kerr, J. B.: New methodology for deriving total ozone and other atmospheric variables from Brewer spectrophotometer direct sun spectra, J. Geophys. Res., 107, 4731, doi:10.1029/2001JD001227, 2002.

Kerr, J. B., McElroy, C. T., Wardle, D. I., Olafson, R. A., and Evans, W. F. J.: The automated brewer spectrophotometer, in: Proc. Of the Quadrennial Ozone Symposium, edited by: Zerefos, C. S. and Ghazi, A., 611-614, D. Reidel Publ. Co., Dordrecht, 1984.

Komhyr, W. D., Barnes, R. A., Brothers, G. B., Lathrop, J. A., and Opperman, D. P.: Electrochemical concentration cell ozonesonde performance evaluation during STOIC 1989, J. Geophys. Res., 100, 9231-9244, doi:10.1029/94JD02175, 1995.

Koukouli, M. E., Balis, D. S., Loyola, D., Valks, P., Zimmer, W., Hao, N., Lambert, J.-C., Van Roozendael, M., Lerot, C., and Spurr, R. J. D.: Geophysical validation and long-term consistency between GOME-2/MetOp-A total ozone column and measurements from the sensors GOME/ERS-2, SCIAMACHY/ENVISAT and OMI/Aura, Atmos. Meas. Tech., 5, 2169-2181, doi:10.5194/amt-5-2169-2012, 2012.

Koukouli, M. E., Lerot, C., Granville, J., Goutail, F., Lambert, J.C., Pommereau, J.-P., Balis, D., Zyrichidou, I., Van Roozendael, M., Coldewey-Egbers, M., Loyola, D., Labow, G., Frith, S., Spurr, R., and Zehner, C.: Evaluating a new homogeneous total ozone climate data record from GOME/ERS-2, SCIAMACHY/Envisat, and GOME-2/MetOp-A, J. Geophys. Res. Atmos., 120, doi:10.1002/2015JD023699, 2015.

Kroon, M., de Haan, J. F., Veefkind, J. P., Froidevaux, L., Wang, R. Kivi, R., and Hakkarainen, J. J.: Validation of operational ozone profiles from the Ozone Monitoring Instrument, J. Geophys. Res., 116, D18305, doi:10.1029/2010JD015100, 2011.

Lerot, C., Van Roozendael, M., Spurr, R., Loyola, D., ColdeweyEgbers, M., Kochenova, S., van Gent, J., Koukouli, M., Balis, D., Lambert, J.-C., Granville, J. and Zehner, C.: Homogenized total ozone data records from the European sensors GOME/ERS2, SCIAMACHY/Envisat, and GOME-2/MetOp-A, J. Geophys. Res. Atmos., 119, 1639-1662, doi:10.1002/2013JD020831, 2014.

Lim, S. S., Vos, T., Flaxman, A. D., Danaei, G., Shibuya, K., Adair-Rohani, H., Amann, M., Anderson, H. R., Andrews, K. G., Aryee, M., Atkinson, C., Bacchus, L. J., Bahalim, A. N.,
Balakrishnan, K., Balmes, J., Barker-Collo, S., Baxter, A., Bell, M. L., Blore, J. D., Blyth, F., Bonner, C., Borges, G., Bourne, R., Boussinesq, M., Brauer, M., Brooks, P., Bruce, N. G., Brunekreef, B., Bryan-Hancock, C., Bucello, C., Buchbinder, R., Bull, F., Burnett, R. T., Byers, T. E., Calabria, B., Carapetis, J., Carnahan, E., Chafe, Z., Charlson, F., Chen, H., Chen, J. S., Cheng, A. T., Child, J. C., Cohen, A., Colson, K. E., Cowie, B. C., Darby, S., Darling, S., Davis, A., Degenhardt, L., Dentener, F., Des Jarlais, D. C., Devries, K., Dherani, M., Ding, E. L., Dorsey, E. R., Driscoll T., Edmond, K., Ali, S. E., Engell, R. E., Erwin, P. J., Fahimi, S., Falder, G., Farzadfar, F., Ferrari, A., Finucane, M. M., Flaxman, S., Fowkes, F. G., Freedman, G., Freeman, M. K., Gakidou, E., Ghosh, S., Giovannucci, E., Gmel, G., Graham, K., Grainger, R., Grant, B., Gunnell, D., Gutierrez, H. R., Hall, W., Hoek, H. W., Hogan, A., Hosgood, H. D. 3rd, Hoy, D., Hu, H., Hubbell, B. J., Hutchings, S. J., Ibeanusi, S. E., Jacklyn, G. L., Jasrasaria, R., Jonas, J. B., Kan, H., Kanis, J. A., Kassebaum, N., Kawakami, N., Khang, Y. H., Khatibzadeh, S., Khoo, J. P., Kok, C., Laden, F., Lalloo, R., Lan, Q., Lathlean, T., Leasher, J. L., Leigh, J., Li, Y., Lin, J. K., Lipshultz, S. E., London, S., Lozano, R., Lu, Y., Mak, J., Malekzadeh, R., Mallinger, L., Marcenes, W., March, L., Marks, R., Martin, R., McGale, P., McGrath, J., Mehta, S., Mensah G. A., Merriman, T. R., Micha, R., Michaud, C., Mishra, V., Mohd Hanafiah, K., Mokdad, A. A., Morawska, L., Mozaffarian, D., Murphy, T., Naghavi, M., Neal, B., Nelson, P. K., Nolla, J. M., Norman, R., Olives, C., Omer, S. B., Orchard, J., Osborne, R., Ostro, B., Page, A., Pandey, K. D., Parry, C. D., Passmore, E., Patra, J. Pelizzari, P. M., Petzold, M., Phillips, M. R., Pope, D., Pope, C. A. 3rd, Powles, J., Rao, M., Razavi, H., Rehfuess, E. A., Rehm, J. T., Ritz, B., Rivara F. P., Roberts, T., Robinson, C., Rodriguez-Portales, J. A., Romieu, I., Room, R. Rosenfeld, L. C., Roy, A., Rushton, L., Salomon, J. A., Sampson, U., Sanchez-Riera, L., Sanman, E., Sapkota, A., Seedat, S., Shi P., Shield, K., Shivakoti, R., Singh, G. M., Sleet, D. A., Smith, E., Smith, K. R., Stapelberg, N. J., Steenland, K., Stöckl, H., Stovner, L. J., Straif, K., Straney, L., Thurston, G. D., Tran, J. H., Van Dingenen, R., van Donkelaar, A., Veerman, J. L., Vijayakumar, L., Weintraub, R., Weissman, M. M., White, R. A., Whiteford, H., Wiersma, S. T., Wilkinson, J. D., Williams, H. C., Williams, W., Wilson, N., Woolf, A. D., Yip, P., Zielinski, J. M., Lopez, A. D., Murray, C. J., Ezzati, M., AlMazroa, M. A., and Memish, Z. A.: A comparative risk assessment of burden of disease and injury attributable to 67 risk factors and risk factor clusters in 21 regions, 1990-2010: a systematic analysis for the Global Burden of Disease study 2010, Lancet 380, 2224-2260, 2012.

Loyola, D. G., Koukouli, M. E., Valks, P., Balis, D. S., Hao, N., Van Roozendael, M., Spurr, R. J. D., Zimmer, W., Kiemle, S., Lerot, C., and Lambert, J.-C.: The GOME-2 total column ozone product: Retrieval algorithm and ground-based validation, J. Geophys. Res., 116, D07302, doi:10.1029/2010JD014675, 2011.

McPeters, R. D., Labow, G. J., and Logan, J. A.: Ozone climatological profiles for satellite retrieval algorithms, J. Geophys. Res., 112, D05308, doi:10.1029/2005JD006823, 2007.

Miles, G. M., Siddans, R., Kerridge, B. J., Latter, B. G., and Richards, N. A. D.: Tropospheric ozone and ozone profiles retrieved from GOME-2 and their validation, Atmos. Meas. Tech., 8, 385-398, doi:10.5194/amt-8-385-2015, 2015. 
Monks, P. S., Archibald, A. T., Colette, A., Cooper, O., Coyle, M., Derwent, R., Fowler, D., Granier, C., Law, K. S., Mills, G. E., Stevenson, D. S., Tarasova, O., Thouret, V., von Schneidemesser, E., Sommariva, R., Wild, O., and Williams, M. L.: Tropospheric ozone and its precursors from the urban to the global scale from air quality to short-lived climate forcer, Atmos. Chem. Phys., 15, 8889-8973, doi:10.5194/acp-15-8889-2015, 2015.

Munro, R., Lang, R., Klaes, D., Poli, G., Retscher, C., Lindstrot, R., Huckle, R., Lacan, A., Grzegorski, M., Holdak, A., Kokhanovsky, A., Livschitz, J., and Eisinger, M.: The GOME2 instrument on the Metop series of satellites: instrument design, calibration, and level 1 data processing - an overview, Atmos. Meas. Tech., 9, 1279-1301, doi:10.5194/amt-9-1279-2016, 2016.

Nassar, R., Logan, J. A., Worden, H. M., Megretskaia, I. A., Bowman, K. W., Osterman, G. B., Thompson, A. M., Tarasick, D. W., Austin, S., Claude, H., Dubey, M. K., Hocking, W. K., Johnson, B. J., Joseph, E., Merrill, J., Morris, G. A., Newchurch, M., Oltmans, S. J., Posny, F., Schmidlin, F. J., Vomel, H., Whiteman, D. N., and Witte, J. C.: Validation of Tropospheric Emission Spectrometer (TES) nadir ozone profiles using ozonesonde measurements, J. Geophys. Res.-Atmos., 113, D15S17, doi:10.1029/2007jd008819, 2008.

O3-CCI: O3-CCI GOME-2 L2 ozone data, available at: www. esa-ozone-cci.org, last access: 31 August 2016.

O3M SAF: O3M SAF GOME-2 L2 ozone data, available at: http: //o3msaf.fmi.fi, last access: 31 August 2016.

Oetjen, H., Payne, V. H., Kulawik, S. S., Eldering, A., Worden, J., Edwards, D. P., Francis, G. L., Worden, H. M., Clerbaux, C., Hadji-Lazaro, J., and Hurtmans, D.: Extending the satellite data record of tropospheric ozone profiles from Aura-TES to MetOp-IASI: characterisation of optimal estimation retrievals, Atmos. Meas. Tech., 7, 4223-4236, doi:10.5194/amt-7-42232014, 2014.

Pastel, M., Pommereau, J.-P., Goutail, F., Richter, A., Pazmiño, A., Ionov, D., and Portafaix, T.: Construction of merged satellite total $\mathrm{O}_{3}$ and $\mathrm{NO}_{2}$ time series in the tropics for trend studies and evaluation by comparison to NDACC SAOZ measurements, Atmos. Meas. Tech., 7, 3337-3354, doi:10.5194/amt-7-3337-2014, 2014.

Picquet-Varrault, B., Orphal., J., Doussin, J.-F., Carlier, P., and Flaud, J.-M.: Laboratory Intercomparison of the Ozone Absorption Coefficients in the Mid-infrared $(10 \mu \mathrm{m})$ and Ultraviolet (300-350 nm) Spectral Regions, J. Phys. Chem. A, 109, 10081014, 2005.

Platt, U.: Differential optical absorption spectroscopy (DOAS), Chem. Anal. Series, 127, 27-83, 1994.

Pommereau, J.-P. and Goutail, F.: Ground-based measurements by visible spectrometry during Arctic Winter and Spring, Geophys. Res. Lett., 15, 891-894, 1988.

Pommier, M., Clerbaux, C., Law, K. S., Ancellet, G., Bernath, P., Coheur, P.-F., Hadji-Lazaro, J., Hurtmans, D., Nédélec, P., Paris, J.-D., Ravetta, F., Ryerson, T. B., Schlager, H., and Weinheimer, A. J.: Analysis of IASI tropospheric $\mathrm{O}_{3}$ data over the Arctic during POLARCAT campaigns in 2008, Atmos. Chem. Phys., 12, 7371-7389, doi:10.5194/acp-12-7371-2012, 2012.

Rodgers, C. D.: Inverse Methods for Atmospheric Sounding: Theory and Practice, Series on Atmospheric, Oceanic and Planetary Physics, vol. 2, World Scientific, Hackensack, Singapore, 2000.
Roscoe, H. K., Johnston, P. V., Van Roozendael, M., Richter, A., Sarkissian, A., Roscoe, J., Preston, K. E., Lambert, J.-C., Hermans, C., Decuyper, W., Dzienus, S., Winterrath, T., Burrows, J. P., Goutail, F., Pommereau, J.-P., D’Almeida, E., Hottier, J., Coureul, C., Didier, R., Pundt, I., Bartlett, L. M., McElroy, C. T., Kerr, J. E., Elokhov, A., Giovanelli, G., Ravegnani, F., Premuda, M., Kostadinov, I., Erle, F., Wagner, T., Pfeilsticker, K., Kenntner, M., Marquard, L. C., Gil, M., Puentedura, O., Yela, M., Arlander, D. W., Kastad Hoiskar, B. A., Tellefsen, C. W., Karlsen Tørnkvist, K., Heese, B., Jones, R. L., Aliwell, S. R., and Freshwater, R. A.: Slant column measurements of $\mathrm{O}_{3}$ and $\mathrm{NO}_{2}$ during the NDSC intercomparison of zenith-sky UV-visible spectrometers in June 1996, J. Atmos. Chem., 32, 281-314, 1999.

Rothman, L.S., Jacquemart, D., Barbe, A., Benner, D.C., Birk, M., Brown, L.R., Carleer, M.R., Chackerian, C., Jr., Chance, K., Coudert, L.H., Dana, V., Devi, V.M., Flaud, J.M., Gamache, R.R., Goldman, A., Hartmann, J.M., Jucks, K.W., Maki, A.G., Mandin, J.Y., Massie, S.T., Orphal, J., Perrin, A., Rinsland, C.P., Smith, M.A.H., Tennyson, J., Tolchenov, R.N., Vander Auwera, J., Varanasi, P., and Wagner, G.: The HITRAN2004 molecular spectroscopic database, J. Quant. Spectrosc. Ra., 96, 139-204, doi:10.1016/j.jqsrt.2004.10.008, 2005.

Rothman, L., Gordon, I., Babikov, Y., Barbe, A., Benner, D. C., Bernath, P., Birk, M., Bizzocchi, L., Boudon, V., Brown, L., Campargue, A., Chance, K., Cohen, E., Coudert, L., Devi, V., Drouin, B., Fayt, A., Flaud, J.-M., Gamache, R., Harrison, J., Hartmann, J.-M., Hill, C., Hodges, J., Jacquemart, D., Jolly, A., Lamouroux, J., Roy, R. L., Li, G., Long, D., Lyulin, O., Mackie, C., Massie, S., Mikhailenko, S., Müller, H., Naumenko, O., Nikitin, A., Orphal, J., Perevalov, V., Perrin, A., Polovtseva, E., Richard, C., Smith, M., Starikova, E., Sung, K., Tashkun, S., Tennyson, J., Toon, G., Tyuterev, V., and Wagner, G.: The HITRAN2012 molecular spectroscopic database, J. Quant. Spectrosc. Ra., 130, 4-50, doi:10.1016/j.jqsrt.2013.07.002, 2013.

Safieddine, S., Clerbaux, C., George, M., Hadji-Lazaro, J., Hurtmans, D., Coheur, P.-F., Wespes, C., Layola, D., Valks, P. and Hao, N.: Tropospheric ozone and nitrogen dioxide measurements in urban and rural regions as seen by IASI and GOME-2. J. Geophys. Res., Atmospheres, 118, 1-12, doi:10.1002/jgrd.50669, 2013.

Safieddine, S., Boynard, A., Coheur, P.-F., Hurtmans, D., Pfister, G., Quennehen, B., Thomas, J. L., Raut, J.-C., Law, K. S., Klimont, Z., Hadji-Lazaro, J., George, M., and Clerbaux, C.: Summertime tropospheric ozone assessment over the Mediterranean region using the thermal infrared IASI/MetOp sounder and the WRF-Chem model, Atmos. Chem. Phys., 14, 1011910131, doi:10.5194/acp-14-10119-2014, 2014.

Safieddine, S., Boynard, A., Hao, N., Huang, F., Wang, L., Ji, D., Barret, B., Ghude, S. D., Coheur, P.-F., Hurtmans, D., and Clerbaux, C.: Tropospheric Ozone Variability during the East Asian Summer Monsoon as Observed by Satellite (IASI), Aircraft (MOZAIC) and Ground Stations, Atmos. Chem. Phys. Discuss., 15, 31925-31950, doi:10.5194/acpd-15-31925-2015, 2015.

SAOZ: SAOZ ozone data, available at: http://saoz.obs.uvsq.fr, last access: 31 August 2016.

Scannell, C., Hurtmans, D., Boynard, A., Hadji-Lazaro, J., George, M., Delcloo, A., Tuinder, O., Coheur, P.-F., and Clerbaux, C.: Antarctic ozone hole as observed by IASI/MetOp for 2008-2010, 
Atmos. Meas. Tech., 5, 123-139, doi:10.5194/amt-5-123-2012, 2012.

Shindell, D., Kuylenstierna, J. C. I., Vignati, E., van Dingenen, R., Amann, M., Klimont, Z., Anenberg, S. C., Muller, N., Janssens-Maenhout, G., Raes, F., Schwartz, J., Faluvegi, G., Pozzoli, L., Kupiainen, K., Höglund-Isaksson, L., Emberson, L., Streets, D., Ramanathan, V., Hicks, K., Oanh, N. T. K., Milly, G., Williams, M., Demkine, V., and Fowler, D.: Simultaneously Mitigating Near-Term Climate Change and Improving Human Health and Food Security, Science, 335, 183-189, doi:10.1126/science.1210026, 2012.

Smit, H. G. J., Straeter, W., Johnson, B., Oltmans, S., Davies, J., Tarasick, D. W., Hoegger, B., Stubi, R., Schmidlin, F., Northam, T., Thompson, A., Witte, J., Boyd, I., and Posny, F.: Assessment of the performance of ECC-ozonesondes under quasi-flight conditions in the environmental simulation chamber: Insights from the Juelich Ozone Sonde Intercomparison Experiement (JOSIE), J. Geophys. Res., 112, D19306, doi:10.1029/2006JD007308, 2007.

Stevenson, D. S., Dentener, F. J., Schultz, M. G., Ellingsen, K., van Noije, T. P. C., Wild, O., Zeng, G., Amann, M., Atherton, C. S., Bell, N., Bergmann, D. J., Bey, I., Butler, T., Cofala, J., Collins, W. J., Derwent, R. G., Doherty, R. M., Drevet, J., Eskes, H. J., Fiore, A. M., Gauss, M., Hauglustaine, D. A., Horowitz, L. W., Isaksen, I. S. A., Krol, M. C., Lamarque, J. F., Lawrence, M. G., Montanaro, V., Muller, J. F., Pitari, G., Prather, M. J., Pyle, J. A., Rast, S., Rodriguez, J. M., Sanderson, M. G., Savage, N. H., Shindell, D. T., Strahan, S. E., Sudo, K., and Szopa, S.: Multimodel ensemble simulations of present-day and near-future tropospheric ozone, J. Geophys. Res.-Atmos., 111, D08301, doi:10.1029/2005jd006338, 2006.

Toihir, A. M., Bencherif, H., Sivakumar, V., El Amraoui, L., Portafaix, T., and Mbatha, N.: Comparison of total column ozone obtained by the IASI-MetOp satellite with ground-based and OMI satellite observations in the southern tropics and subtropics, Ann. Geophys., 33, 1135-1146, doi:10.5194/angeo-331135-2015, 2015.

Valks, P., Hao, N., Gimeno Garcia, S., Loyola, D., Dameris, M., Jöckel, P., and Delcloo, A.: Tropical tropospheric ozone column retrieval for GOME-2, Atmos. Meas. Tech., 7, 2513-2530, doi:10.5194/amt-7-2513-2014, 2014.

Van Roozendael, M., Spurr, R., Loyola, D., Lerot, C., Balis, D., Lambert, J.-C., Zimmer, W., van Gent, J., van Geffen, J., Koukouli, M., Granville, J., Doicu, A., Fayt, C., and Zehner, C.: Sixteen years of GOME/ERS-2 total ozone data: The new direct-fitting GOME Data Processor (GDP) version 5 - Algorithm description, J. Geophys. Res., 117, D03305, doi:10.1029/2011JD016471, 2012.
Verstraeten, W. W., Boersma, K. F., Zörner, J., Allaart, M. A. F., Bowman, K. W., and Worden, J. R.: Validation of six years of TES tropospheric ozone retrievals with ozonesonde measurements: implications for spatial patterns and temporal stability in the bias, Atmos. Meas. Tech., 6, 1413-1423, doi:10.5194/amt-61413-2013, 2013.

Verstraeten, W. W., Neu, J. L., Williams, J. E., Bowman, K. W., Worden, J. R., and Boersma, K. F.: Rapid increases in tropospheric ozone production and export from China, Nat. Geosci., 8, 690-695, doi:10.1038/ngeo2493, 2015.

Wagner, G., Birk, M., Schreier, F., and Flaud, J.-M.: Spectroscopic database for ozone in the fundamental spectral regions, J. Geophys. Res., 107, 4626, doi:10.1029/2001JD000818, 2002.

Weber, M., Lamsal, L. N., Coldewey-Egbers, M., Bramstedt, K., and Burrows, J. P.: Pole-to-pole validation of GOME WFDOAS total ozone with groundbased data, Atmos. Chem. Phys., 5, 1341-1355, doi:10.5194/acp-5-1341-2005, 2005.

Wespes, C., Emmons, L., Edwards, D. P., Hannigan, J., Hurtmans, D., Saunois, M., Coheur, P.-F., Clerbaux, C., Coffey, M. T., Batchelor, R. L., Lindenmaier, R., Strong, K., Weinheimer, A. J., Nowak, J. B., Ryerson, T. B., Crounse, J. D., and Wennberg, P. $\mathrm{O}$.: Analysis of ozone and nitric acid in spring and summer Arctic pollution using aircraft, ground-based, satellite observations and MOZART-4 model: source attribution and partitioning, Atmos. Chem. Phys., 12, 237-259, doi:10.5194/acp-12-237-2012, 2012.

Wespes, C., Hurtmans, D., Emmons, L. K., Safieddine, S., Clerbaux, C., Edwards, D. P., and Coheur, P.-F.: Ozone variability in the troposphere and the stratosphere from the first 6 years of IASI observations (2008-2013), Atmos. Chem. Phys., 16, 5721-5743, doi:10.5194/acp-16-5721-2016, 2016.

Worden, H. M., Logan, J. A., Worden, J. R., Beer, R., Bowman, K., Clough, S. A., Eldering, A., Fisher, B. M., Gunson, M. R., Herman, R. L., Kulawik, S. S., Lampel, M. C., Luo, M., Megretskaia, I. A., Osterman, G. B., and Shephard, M. W.: Comparisons of Tropospheric Emission Spectrometer (TES) ozone profiles to ozonesondes: Methods and initial results, J. Geophys. Res., 112, D03309, doi:10.1029/2006JD007258, 2007.

Worden, H. M., Bowman, K. W., Worden, J. R., Eldering, A., and Beer, R.: Satellite measurements of the clear-sky greenhouse effect from tropospheric ozone, Nat. Geosci., 1, 305-308, 2008.

WOUDC: Brewer, Dobson and ozonesonde data, available at: http: //www.woudc.org, last access: 31 August 2016. 